\title{
Tributação e desenvolvimento regional: uma análise econômica dos benefícios fiscais concedidos para empresas instaladas na Zona Franca de Manaus e a guerra fiscal entre estados
}

\author{
Taxation and regional development : law and \\ economic analysis of the tax benefits granted to \\ companies established in the Manaus Tax Free Zone \\ and the Tax War between the Brazilian States
}

\section{Oksandro Osdival Gonçalves* Marcelo Miranda Ribeiro*}

\section{Resumo}

No artigo, analisa-se, sob a perspectiva da Análise Econômica do Direito (AED), as repercussões econômicas advindas da instituição de incentivos fiscais, sejam os concedidos pela chamada "guerra fiscal", sejam os outorgados de forma legal. Para tal fim, examinam-se algumas noções fundamentais da AED (suas premissas básicas, custos de transação, falhas de mercado e critérios de eficiência de Pareto e Kaldor-Hicks). Aborda-se o que são incentivos fiscais, assim como discute-se o princípio da neutralidade fiscal e as formas legítimas de intervenção do Estado na ordem econômica. Por fim, apresentam-se dois estudos de caso: o primeiro relativo aos benefícios especiais concedidos a empresas instaladas na Zona Franca de Manaus, no setor de refrigerantes, o segundo relativo à concessão de incentivos fiscais ilegais em parecer

* Doutor em Direito Comercial - Direito das Relações Sociais pela Pontifícia Universidade Católica de São Paulo. Professor do Programa de Pós-Graduação em Direito (Mestrado/Doutorado) da Pontifícia Universidade Católica do Paraná. Professor Adjunto de Direito Comercial do Curso de Direito da Pontifícia Universidade Católica do Paraná. Professor de Direito Empresarial do Curso de Especialização em Direito Civil e Empresarial da Pontifícia Universidade Católica do Paraná. Membro do Conselho Editorial da Editora Fórum. Coordenador da Revista de Direito Empresarial. Doutor em Direito Comercial - Direito das Relações Sociais pela Pontifícia Universidade Católica de São Paulo. Mestre em Direito Econômico pela Pontifícia Universidade Católica do Paraná. Advogado. Curitiba - PR - Brasil. Email: oksandro@ cgaadv.com.br

** Mestre em Direito pela Pontifícia Universidade Católica do Paraná (2011/2013). Auditor Fiscal da Receita Federal. Especialista em Direito Público pela Unibrasil (2010). Graduado em Ciência da Computação pela Universidade Federal de Viçosa (1992) e em Direito pela Universidade Federal do Paraná (2009). Curitiba - PR - Brasil. Email: marcelomirandaribeiro@yahoo.com.br 
respondido pelo Conselho Administrativo de Defesa Econômica. A importância da AED neste estudo é fulcral, pois coloca no centro dos estudos jurídicos os problemas relativos às consequências econômicas das intervenções jurídicas. Com a sua utilização, é possível demonstrar que os mecanismos extrafiscais de correção de falhas de mercado ou como estratégias de desenvolvimento regional apresentam importantes limites. Enfim, como se revela, benefícios fiscais só poderão ser utilizados, sem serem injustos, se forem instituídos por inequívocas razões do bem comum, necessários para o fomento da economia no seu todo e efetivamente adequados para a consecução dos respectivos objetivos.

Palavras-chave: Análise econômica do direito. Incentivos fiscais. Neutralidade fiscal.

\section{Abstract}

The paper analyzes, from the perspective of Economic Analysis of Law (AED), the economic repercussions resulting from the imposition of tax incentives granted by referred "war tax" and legally granted. To this end, it will be necessary to examine some fundamental notions of AED (its basic premises, transaction costs, market failures and efficiency criteria of Pareto and Kaldor-Hicks). Will also be studied what are tax incentives, as will be analyzed the principle of fiscal neutrality and the legitimate forms of state intervention in the economic order. Finally, it presents two case studies: the first on the special benefits granted to companies established in the Manaus Free Zone in the soft drinks sector and the second on the granting of illegal tax incentives answered by the Administrative Council for Economic Defense. The importance of AED in this study is crucial, because it puts at the center of legal studies issues relating to economic consequences of legal intervention. With its use will be possible to demonstrate that the mechanisms extrafiscal correction of market failures or as regional development strategies have important limitations. At last, as will be revealed, tax benefits can only be used, without being unjust, if established by clear reasons for the common good, necessary for the promotion of the economy as a whole and appropriate effectively to achieve their goals.

Keywords: Economic analysis of law. Tax incentives. Fiscal neutrality.

\section{Introdução}

A Constituição Federal determina que são objetivos fundamentais da República Federativa do Brasil a construção de uma sociedade 
livre, justa e solidária; garantir o desenvolvimento nacional; erradicar a pobreza e reduzir as desigualdades sociais e regionais; e promover o bem de todos. Para a consecução de tais fins, obviamente, o Estado necessidade de vultosos recursos financeiros. Tributos existem, portanto, para viabilizar a consecução dos fins constitucionalmente previstos. Afinal, é com a arrecadação tributária que se gera a maior parte das receitas públicas. Por isso, como afirma José Casalta Nabais (1998, p. 679), os tributos são o "contributo indispensável a uma vida em comunidade organizada".

Porém, a tributação deve ser realizada com o mínimo de efeitos econômicos negativos. Quando o Estado institui um tributo sobre as trocas econômicas, o sistema de preços do mercado sofre ruído, pois o produtor é obrigado a repassar o custo da tributação para o preço do bem. Por isso, perdem o consumidor e o produtor: o primeiro em função do aumento de preço do bem, e o segundo em virtude da redução de seu lucro. Há perda de bem-estar para ambos. Esse é o peso morto da tributação: menos produção e menos consumo, resultando em menos riqueza para a sociedade (CARVALHO, 2008, p. 194).

Mas não é só a instituição de tributos (ou sua majoração) que causas ineficiências econômicas. As desonerações tributárias, ao contrário do que à primeira vista pode parecer, são mecanismos que também podem gerar desajustes no mercado. Isso ocorre porque tanto a tributação quanto a sua desoneração alteram o preço relativo dos bens e, por conseguinte, podem provocar externalidades negativas.

Como se constata, Direito Tributário e Economia possuem estreita relação, pois tributos representam importantes cursos de transação. Todavia, "a relação entre o Direito e a Economia, especificamente no ramo do Direito Tributário brasileiro, não tem sido objeto de estudos aprofundados" (LA GUARDIA, 2007, p. 3). Por sua vez, o legislador apenas calcula as possíveis "receitas tributárias" ou "perdas de arrecadação" antes da edição de um projeto de lei tributária. Igualmente, Ministros do STF, ao julgarem a inconstitucionalidade de leis tributárias, formam parte de seu convencimento com base no prejuízo financeiro que 
a decisão pode causar à União. ${ }^{1}$ Em outros termos, a Análise Econômica no Direito Tributário volta-se principalmente para o cálculo dos valores a serem arrecadados ou desonerados pelas leis tributárias. Não há, nesse caso, um estudo efetivo dos impactos econômicos de uma lei tributária, como o estímulo à sonegação ou a migração das organizações para setores menos onerados pela carga tributária (LA GUARDIA, 2007, p. 4). Enfim, o que há, normalmente, é uma mera previsão aritmética de ganho ou perda de arrecadação, o que está muito longe de ser uma análise econômica do Direito Tributário.

Diante desse contexto, o objetivo deste artigo é avaliar, sob a perspectiva da Análise Econômica do Direito (AED), os impactos econômicos da tributação sobre o desenvolvimento regional. Entretanto, o foco não são as repercussões econômicas oriundas da instituição de novas exações ou da majoração de tributos existentes. O que se pretende é fazer uma análise das repercussões econômicas dos incentivos fiscais, sejam os concedidos pela chamada "guerra fiscal", sejam os outorgados de forma legal. Para tal desiderato, será necessário examinar algumas noções fundamentais da AED, assim como estudar determinados aspectos do Direito Tributário, indispensáveis ao entendimento do problema apresentado (conceituar incentivos fiscais, avaliar os princípios da neutralidade fiscal e da livre concorrência e estudar as formas legítimas de intervenção do Estado na ordem econômica). Por fim, serão apresentados dois estudos de caso: o primeiro relativo à análise do setor de refrigerantes e às repercussões econômicas de isenções e creditamentos especiais concedidos a empresas instaladas na Zona Franca de Manaus, e o segundo relativo à instituição de incentivos fiscais concedidos na chamada "guerra fiscal".

Como exemplo, citem-se os Recursos Extraordinários ns 556.664 e 559.882 , nos quais, em 12/06/2008, o STF modulou os efeitos da declaração de inconstitucionalidade dos artigos 45 e 46 , da Lei Federal $n^{\circ} 8.212 / 91$, definindo como inconstitucional o prazo prescricional e decadencial de dez anos, mas limitando a eficácia retroativa destas decisões. Ao assim decidir, a Corte Suprema determinou que os efeitos de sua decisão não atingiriam os contribuintes que haviam pagado as contribuições e não haviam iniciado a discussão sobre a legalidade do referido tributo até a data da conclusão do julgamento (BRASIL, 2008). 


\section{Noções fundamentais de análise econômica do direito}

O movimento conhecido como Análise Econômica do Direito (AED), ou "law and economics", pode ser definido como a "aplicação da teoria econômica para o exame de formação, estruturação e impacto da aplicação de normas e instituições jurídicas", chamando a atenção dos juristas para uma nova maneira de se analisar o fenômeno jurídico (RIBEIRO, 2009, p. 53).

Não se trata de uma aplicação direta da teoria econômica sobre o Direito, mas o desenvolvimento de "ferramentas epistemológicas não originalmente disponíveis na Ciência Jurídica ou na Ciência da Economia, tradicionalmente reducionistas, mas a relação entre ambos os domínios da realidade social" (CARVALHO, 2008, p. 239).

Assim, a AED coloca no centro dos estudos jurídicos "os problemas relativos à eficiência do Direito, o custo dos instrumentos jurídicos na persecução de seus fins e as consequências econômicas das intervenções jurídicas" (RIBEIRO, 2009, p. 67-68). Exatamente por esse motivo ela é uma ferramenta adequada à análise do objeto de estudo, já que aproxima Direito Tributário e Economia, aproximação essencial para sintonizar "a justiça tributária à justiça econômica" (FORTES; BASSOLI, 2010, p. 237).

\subsection{Análise positiva e normativa do direito}

A AED utiliza dois níveis epistemológicos para relacionar Direito e Economia: a dimensão positiva (ou descritiva) e a dimensão normativa (ou prescritiva). À primeira dá-se o nome de Análise Positiva do Direito, que se ocupa em estudar as repercussões práticas do Direito sobre o mundo real; e à segunda dá-se o nome de Análise Normativa do Direito, a qual estuda como a noção de justiça se comunica com conceitos de eficiência econômica, maximização da riqueza e maximização de bemestar (SALAMA, 2007, p. 5).

O argumento central da Análise Positiva do Direito é o de que os conceitos microeconômicos são úteis para a análise do Direito. Bruno 
Salama (2007, p. 10) observa que esse argumento possui diversas versões, três das quais podem ser destacadas: a reducionista, a explicativa e a preditiva.

A versão reducionista - minoritária e pouco proveitosa - sugere que o Direito pode ser reduzido à Economia e que categorias jurídicas tradicionais (como direitos subjetivos, deveresjurídicos, culpa, negligência etc.) podem ser substituídas por categorias econômicas. A segunda versão diz respeito à capacidade explicativa da teoria econômica. A ideia é a de que os sistemas jurídicos podem ser compreendidos como sendo a resultante da maximização de recursos escassos por parte das pessoas, que ocorre de forma relativamente coordenada. Por exemplo, a regra geral da responsabilização subjetiva, baseada na existência de culpa, seria explicada como resultante da tentativa de dar incentivos para que tanto os potenciais causadores de danos quanto as potenciais vítimas tomem atitudes para mitigarem as chances de ocorrência de danos. O problema é que a explicação de institutos jurídicos deixa de lado uma série de fatores culturais e históricos, o que significa dizer que a economia não explica completamente o Direito, já que não capta toda a realidade subjacente. A terceira versão do argumento é a de que a Economia pode ser aproveitada para prever as consequências de diversas regras jurídicas. Trata-se de tentar identificar os prováveis efeitos das regras jurídicas sobre o comportamento dos atores sociais relevantes em cada caso. A AED retira as consequências do fenômeno jurídico da periferia, trazendo-as para o centro do debate, de modo a ser possível ao profissional do Direito entender os prováveis efeitos que advirão das diferentes posturas legais (SALAMA, 2007, p. 10-11).

Na lição de Cristiano Carvalho (2008, p. 191), a Análise Positiva do Direito é o ramo da análise econômica que descreve como a economia de fato funciona. Ela avalia como ocorrem as trocas econômicas em um dado mercado e permite prever o comportamento desses mercados (ex.: tributação excessiva gera incentivos à informalidade). Por sua vez, a Análise Normativa do Direito é o ramo da análise econômica em que são feitas prescrições sobre como a economia deveria funcionar, ou seja, serve para propor o que seria melhor para a sociedade. 
Enfim, enquanto a análise jurídica positiva refere-se ao Direito como ele é num dado sistema jurídico particular, a análise jurídica normativa propõe alterações no sistema, de modo a alcançar um dado objetivo previamente estabelecido.

Cabe ressalvar, porém, que a AED é incapaz de dizer o que é justo ou injusto, ou o que é certo ou errado, pois essas categorias encontram-se no mundo dos valores e são, portanto, subjetivas. Porém, para a AED, não importa qual política pública uma dada comunidade deseja implementar, uma vez escolhida, seja ela qual for, não existe justificativa moral para que sua implementação seja realizada de forma a gerar desperdícios. Sob essa perspectiva, a AED não serve para indicar qual o caminho justo, mas pode contribuir para a identificação do que é injusto, pois toda regra que gera desperdício é ineficiente e injusta (GICO JÚNIOR, 2010, p. 27).

\subsection{Premissas fundamentais para aplicação da AED}

Segundo Márcia Carla Pereira Ribeiro (2009, p. 77), as premissas da AED estão fincadas em três princípios principais: escolha racional ou maximização, equilíbrio e eficiência.

A premissa comportamental é a de que os indivíduos farão escolhas que atendam seus interesses pessoais, sejam eles quais forem. Isso significa dizer que indivíduos racionalmente maximizam seu bem-estar (SALAMA, 2007, p. 14). Em outros termos, dizer que os indivíduos são racionais implica concluir que eles buscam otimizar a sua utilidade. Ser racional, portanto, significa ser capaz de efetuar escolhas consistentes, completas e transitivas. Em outros termos, o indivíduo deve ser capaz de estabelecer a sua preferência em face de suas alternativas. Por exemplo, deve ser capaz de dizer que prefere $A$ a $B$, e deve ser capaz de perceber que se prefere $A$ a $B$ e $B$ a $C$, então necessariamente prefere $A$ a C (CARVALHO, 2008, p. 188).

Por isso, os indivíduos reagem a incentivos, entre os quais se encontram as normas jurídicas. A sanção da norma jurídica é processada 
como um preço pelo seu destinatário. As pessoas reagem às sanções da mesma forma como reagem aos preços: ao tomar o comando normativo como um preço, o receptor da norma, automaticamente, por ser racional, avalia a relação entre custo e benefício da conduta que poderia vir a praticar (CARVALHO, 2008, p. 188).

Por sua vez, o conceito de equilíbrio é o padrão comportamental que se atinge quando todos os atores estão maximizando os próprios interesses simultaneamente. A ideia de que indivíduos podem agir como maximizadores racionais de suas preferências e dão ensejo a padrões interativos relativamente estáveis sugere que os indivíduos podem também responder a incentivos. É importante notar que incentivos legais podem gerar efeitos em direções opostas. Por exemplo: a eliminação do foro privilegiado para congressistas poderia causar alguma diminuição da corrupção (fruto de maior temor da sanção criminal), mas poderia também causar diminuição da liberdade de expressão política dos congressistas (fruto do maior temor da perseguição política) (SALAMA, 2007, p. 18-21). De todo modo, quando todos os sujeitos agem em prol de seu autointeresse racional, o resultado acaba sendo uma tendência para o equilíbrio, simplesmente porque as ações individuais acabam não tendo mais poder de influenciar o sistema (ou o mercado) do que as outras (CARVALHO, 2008, p. 189).

Relativamente ao conceito de eficiência, Salama (2007, p. 21) aponta que um dos seus significados mais importantes diz respeito à maximização da riqueza e do bem-estar. Sob essa ótica, a eficiência é a busca da otimização da relação entre output e input. Em termos jurídicos, uma lei será mais eficiente que outra se for capaz de atingir os mesmos resultados através de custos menores. Esses custos não precisam ser necessariamente financeiros, mas podem envolver também custos pessoais, morais ou mesmo o que a Economia denomina de curso social (que envolve as externalidades), custos de oportunidade ou custos de transação. O ponto polêmico nessa premissa é a dicotomia ou o trade off entre eficiência e justiça a se buscar com determinada norma jurídica (CARVALHO, 2008, p. 190). 
Há, contudo, outras duas acepções do termo "eficiência" mais interessantes em função do objeto do estudo aqui desenvolvido: os critérios de eficiência de Pareto e de Kaldor-Hicks, a seguir descritas.

\subsection{Critérios de eficiência de Pareto e Kaldor-Hicks}

Segundo ensina Márcia Carla Pereira Ribeiro (2009, p. 79), uma situação econômica é ótima no sentido de Pareto se não for possível melhorar a situação ou a utilidade de um agente sem degradar a situação de qualquer outro agente econômico. Por essa perspectiva, tem-se que a melhor alocação de recursos incrementa o bem-estar e o fluxo das relações econômicas. Essa alocação mais eficiente, conforme o postulado conhecido como ótimo de Pareto, só ocorre se em uma sociedade não houver mais nenhuma modificação possível a fim de melhorar a situação de alguém sem piorar a de outrem.

A seu turno, Rachel Sztajn (2005, p. 76) aduz, na mesma linha, que, segundo o critério de eficiência de Pareto, não seria possível melhorar a posição de qualquer pessoa sem que houvesse a piora na condição de outrem. Por tal motivo, destaca Ribeiro que tal critério de eficiência "não tem grande aplicação prática, uma vez que a maioria das transações tem efeitos sobre terceiros, sendo praticamente impossível que em uma relação de troca não haja prejuízo, ainda que indireto, para alguém" (RIBEIRO, 2009, p. 87).

O critério de eficiência de Kaldor-Hicks, por sua vez, parte da premissa de que as normas devem ser planejadas com o objetivo de causar o máximo bem-estar para o maior número de pessoas, de modo que os ganhos totais compensem as eventuais perdas sofridas por alguns, ou seja, "as normas devem ser desenhadas de maneira a gerarem o máximo de bem-estar para o maior número de pessoas" (SZTAJN, 2005, p. 76).

Por isso, o critério de Kaldor-Hicks ganhou proeminência entre os adeptos da AED. A eficiência perante esse critério se dá quando a disputa pela alocação de recursos resulta em que o proveito para os 
vencedores Ihes permita compensar os perdedores. Por tal motivo, o referido critério passa a ser o norte para decisões na elaboração das políticas públicas, pois busca mitigar o problema da melhor alocação para todos (Pareto), de forma que a escolha seja pela alternativa que maximiza a riqueza (RIBEIRO, 2009, p. 88-89).

\subsection{Falhas de mercado}

Falhas de mercado são oriundas de situações em que a "homoestase ou a mão invisível não é o suficiente para corrigir desvios do sistema econômico" (CARVALHO, 2008, p. 202). Em termos mais simples, uma falha de mercado ocorre quando os mecanismos de mercado, não regulados pelo Estado e deixados livremente ao seu próprio funcionamento, originam resultados econômicos ineficientes ou indesejáveis socialmente.

Essas falhas são provocadas pelas imperfeições do mercado, notadamente, a existência de poder econômico díspar entre os agentes, assimetria de informação ou informação incompleta dos agentes econômicos, bens públicos e externalidades (RIBEIRO, 2009, p. 93).

Num mercado sem assimetria de informação, vendedores e compradores conhecem os bens e serviços que negociam, conhecem as condições de mercado e têm liberdade para entrar e sair dele. As empresas, por sua vez, conhecem adequadamente as técnicas de produção, e os consumidores conhecem as características dos produtos, suas vantagens, diferentes preços e condições. Isso, no entanto, não é o usual no mercado, preponderando a existência de informações incompletas por parte dos agentes econômicos, como ocorre, por exemplo, com o mercado de veículos usados, no qual o vendedor tem muito mais informação do que o comprador sobre o bem a ser negociado. A importância das falhas de mercado é que elas são, normalmente, entraves para a obtenção de relações econômicas mais eficientes (RIBEIRO, 2009, p. 94).

Outra falha de mercado é a existência de poder econômico. Nessa situação, o mercado não é competitivo e uma ou mais empresas 
abusam de seu poder de mercado, que é a possibilidade de fixar preços acima dos custos marginais (RIBEIRO, 2009, p. 95).

Externalidades, por sua vez, é o custo ou benefício que um agente, na realização de uma atividade econômica, impõe a terceiro, fora do sistema de preços. Ou seja, é o impacto das ações de uma pessoa sobre o bem-estar de outras que não participam da ação.

Para Coelho (2007, p. 34), externalidade é "todo efeito produzido por um agente econômico que repercute positiva ou negativamente sobre a atividade econômica, renda ou bem-estar de outro agente econômico, sem a correspondente compensação". Afirma também a existência de externalidades relevantes e irrelevantes, das quais apenas as primeiras são fatos jurídicos:

Quer dizer, uma vez conferida relevância a certos efeitos produzidos por um empreendimento econômico - a indústria polui e gera empregos -, cabe discutir como se proceder à sua compensação, por meio da imputação de obrigações ao empresário pelos efeitos considerados negativos, e do reconhecimento de direitos em relação aos reputados positivos. Por definição, quando uma externalidade é compensada ela deixa de ser externalidade. É, por assim dizer, internalizada. Internalizar as externalidades para equalizar a relação custos-benefícios sociais é, em termos jurídicos, impor deveres e garantir direitos para fazer justiça.

A partir dessas premissas, surgem duas concepções que tentam explicar a internalização de externalidades: a teoria da economia do bem-estar e a da análise econômica do direito. No caso da primeira, as externalidades seriam falhas no mercado que cabe ao Estado corrigir. A segunda, plasmada na Escola de Chicago, pretende conciliar a aplicação de normas jurídicas a padrões de eficiência econômica. Para esta, as externalidades não são falhas no mercado, mas situações conflituosas que os próprios participantes devem solucionar. Neste último caso, ao Direito compete reduzir os custos de transação que são fruto desse entendimento entre os participantes para alocação das externalidades (COELHO, 2007, p. 35). 
A poluição do meio ambiente é um exemplo clássico de externalidade negativa, mas a mesma indústria que polui é aquela que gera empregos; assim, é preciso verificar a relevância da externalidade em cada caso. Tal conceito é relevante porque indica que algumas decisões podem ser eficientes no plano individual, mas não no plano coletivo. Ademais, a existência de externalidades negativas faz com que os mercados aloquem recursos de forma ineficiente. No exercício da atividade econômica, o papel do Direito, em face das externalidades negativas, é desestimular as atividades lesivas à eficiência coletiva (RIBEIRO, 2009, p. 101).

A importância das falhas de mercado, no entanto, pelo menos no que diz respeito ao objeto deste estudo (incentivos fiscais e suas repercussões econômicas), não é precisamente estudar o que são, mas demonstrar que a sua existência é uma das justificativas para a intervenção estatal por indução (a outra é a busca de desenvolvimento regional). Assim, a concessão de benefícios fiscais por um Estado gera uma perspectiva desenvolvimentista, porque supostamente serve para atrair uma empresa ou um conjunto de empresas de um determinado segmento. Por outro lado, essa conduta gera externalidades negativas, tais como: beneficia o Estado que concede mais benefícios fiscais, embora não se preocupe com infraestrutura e educação; impede que outros Estados, talvez menos interessantes, possam receber empresas e assim modificar a perspectiva do seu desenvolvimento, dentre outros aspectos.

No entanto, como muito bem observa Bruno Salama (2007, p. 20), "demonstrar a existência de falhas de mercado é um exercício intelectual muito interessante; tão interessante quanto incompleto". Ou seja, teoricamente, é fácil utilizar as falhas de mercado como pressuposto para a adoção de mecanismos de correção deste. O difícil é adotar políticas públicas efetivas. Nesse sentido, é muito perspicaz a afirmação de Salama (2007, p. 10), para quem "as falhas de mercado geralmente coexistem com falhas de regulação, de modo que a questão não é tanto se o mercado falha, mas sim se a regulação falhará menos". 


\subsection{Custos de transação}

Custos de transação são os custos incorridos pelos agentes econômicos na procura, aquisição de informação e negociação com outros agentes, com vistas à realização de uma transação, assim como na tomada de decisão acerca da concretização ou não da transação e no monitoramento e exigência do cumprimento, pela outra parte, do que foi negociado (PINHEIRO; SADDI, 2005, p. 75). Spinelli (2007, p. 169) trata dos custos de transação como friç̧ões:

E isto ocorre porque existem custos para que se possa nele contratar (ou seja, para que se possa colocar o sistema em operação) e fazer com que as informações circulem de maneira totalmente livre, uniforme e eficiente. Estes custos, que passaram a ser estudados pela Economia Institucional, principalmente seguindo as pesquisas pioneiras de Ronald Coase (1937), são denominados custos de transação, constituindo atritos, fricções, que existem nas relações transacionais.

O incentivo fiscal é um custo de transação a ser considerado, e é capaz de alterar a tomada de decisões das empresas no momento de uma expansão industrial, por exemplo, porque a escolha racional levará uma nova unidade da empresa para o local que fornecer os melhores benefícios fiscais.

Custo de transação é expressão que, também esta, vem da ciência econômica e cuja relevância, na tomada de decisões pelos agentes econômicos, demonstrase crescente. Transação, no jargão dos economistas, é qualquer operação econômica, operação de circulação de riqueza entre agentes econômicos. Custos de transação são aqueles custos em que se incorre que, de alguma forma, oneram a operação, mesmo quando não representados por dispêndios financeiros feitos pelos agentes, mas que decorre do conjunto de medidas tomadas para realizar uma transação. (SZTAJN, 2004, p. 9).

Segundo apontam Pinheiro e Saddi (2005, p. 62), custo de transação é um conceito fundamental da teoria neoinstitucionalista. 
Eles compreendem cinco atividades que são necessárias para viabilizar a concretização de uma transação. Primeiro, a atividade da busca pela informação sobre regras de distribuição de preço e qualidade das mercadorias, sobre insumos de trabalho e a busca por potenciais compradores e vendedores, assim como a informação relevante sobre o comportamento desses agentes e a circunstância em que operam. Segundo, a atividade de negociação, que será necessária para determinar as verdadeiras intenções e os limites de compradores e vendedores na hipótese de a determinação dos preços ser endógena. Terceiro, a realização e formalização dos contratos, de acordo com as normas legais. Quinto, o monitoramento dos parceiros contratuais, com o intuito de verificar se as formas contratuais estão sendo devidamente cumpridas. Finalmente, a correta aplicação do contrato.

Já para Cooter e Ullen (2010, p. 105-107), os custos de transação se dividem em três espécies: primeiramente, é preciso localizar um parceiro comercial; em segundo lugar, uma negociação tem de ser fechada entre os parceiros comerciais; em terceiro, depois de finalizada a negociação, é preciso fazer com que ela seja cumprida. Ou seja, os custos de transação são os custos de busca, de negociação e de cumprimento do que foi negociado.

Em suma, os custos de transação referem-se não ao custo das mercadorias, bens e serviços em si mesmos ou aos custos de produção, mas aos custos, como o próprio nome indica, da transação. Diante disso, vê-se que tanto os tributos quanto as normas tributárias relacionadas ao ambiente econômico e empresarial impactam fortemente os custos de transação, já que aumentam a complexidade do ambiente de negócios e alteram a perspectiva da tomada de decisões.

Cabe destacar, ainda, outro importante aspecto da teoria dos custos de transação. De acordo com a teoria neoinstitucionalista, o principal papel das instituições é reduzi-los, ou seja, fazer com que os agentes econômicos transacionem a um custo mais baixo, reduzindo a complexidade e facilitando as relações comerciais. É nessa perspectiva que entra o Direito, como instituição adequada a facilitar a cooperação 
entre os agentes econômicos (PINHEIRO; SADDI, 2005, p.62-63). Conforme preconizam os autores:

O modo de entender o papel dos sistemas legal e judicial na economia é como instituições que reduzem os custos de transação, facilitando transações entre desconhecidos, balizando o que pode ser negociado e identificando as responsabilidades de cada um, permitindo a elaboração de contratos mais simples e fornecendo mecanismos que garantam o seu cumprimento (PINHEIRO; SADDI, 2005, p. $64)$.

Em suma, os custos de transação são bastante importantes para o Direito, uma vez que, havendo a presença de custos elevados de busca, acordo ou execução, há a necessidade de intervenção jurídica, a fim de tornar mais eficientes as relações econômicas.

\section{0 desenvolvimento}

Uma das primeiras dificuldades no estudo do desenvolvimento é definir qual é o seu significado.

\subsection{O que é desenvolvimento?}

Basicamente, são duas linhas de pensamento: a) a primeira linha sustenta que desenvolvimento significa crescimento econômico, ou seja, quanto maior este, maior aquele; b) a segunda linha sustenta que o desenvolvimento deve refletir-se na sociedade em geral, com uma interface mais forte em relação a temas como direitos humanos, sustentabilidade e redistribuição da justiça.

Amartya Sen $(2010$, p. 16$)$ ressalta que o desenvolvimento pode ser visto também como forma de expressão da liberdade, criticando a visão que ressalta apenas o aspecto econômico:

O enfoque nas liberdades humanas contrasta com visões mais restritas de desenvolvimento, como as que identificam desenvolvimento com crescimento do Produto Nacional 
Bruto (PNB), aumento de rendas pessoais, industrialização, avanço tecnológico ou modernização social.

O crescimento do PNB ou das rendas individuais obviamente pode ser muito importante como um meio de expandir as liberdades desfrutadas pelos membros da sociedade. Mas as liberdades dependem de outros determinantes, como as disposições sociais e econômicas (por exemplo, os serviços de educação e saúde) e os direitos civis (por exemplo, a liberdade de participar de discussões e averiguações públicas).

Neste trabalho, sustentamos que o desenvolvimento não pode se dar às custas dos valores sociais, que são igualmente importantes. Assim, não é possível sustentar o desenvolvimento à custa de danos ao meio ambiente ou ofensas aos direitos humanos. Logo, as duas linhas mencionadas anteriormente não sobrevivem uma sem a outra. Em parte, essa polaridade mantém-se de outra forma, porque de um lado existe um modelo proposto pela China, que prescinde de maiores considerações aos direitos humanos e ambientais; e de outro, um modelo ocidental, que atualmente está passando por uma grande crise financeira e institucional. Dessa forma, as duas linhas apresentam pontos positivos e negativos, de tal sorte que a melhor abordagem indica a necessidade de adaptação para criar uma terceira linha, que alie crescimento econômico aos valores modernos, como os direitos humanos e os direitos ambientais, rumando para o desenvolvimento sustentável. Nesse ponto, a abordagem também se dá a partir da nova economia institucional,

que considera o projeto e o funcionamento das instituições do setor público e das organizações do setor privado que interagem com essas instituições fatores determinantes essenciais das perspectivas de desenvolvimento dos países, por meio dos incentivos que criam para participar em atividades socialmente produtivas ou improdutivas (DAVIS; TREBILCOCK, 2009, p. 223).

O reconhecimento da importância das instituições é fator determinante neste estudo, em que se propõe a análise dos 
incentivos fiscais e como eles afetam - positiva ou negativamente - o desenvolvimento econômico.

\subsection{O consenso de Washington, o rule of law e o desenvolvimento}

A polarização econômico-política ocorrida predominantemente a partir do final da Segunda Guerra Mundial colocou em discussão não somente aspectos atinentes ao poderio militar de cada um dos polos, mas também um conjunto de outros temas foi trazido à tona para tentar demonstrar ao lado oposto qual era o melhor. Desde questões esportivas até legais e econômicas foram envolvidas nessa disputa como forma de afirmação de um sobre o outro.

Em razão disso, a polarização deu-se entre sistemas democráticos (em alguns casos, apenas supostamente democráticos) que adotavam o capitalismo e sistemas comunistas que adotavam o socialismo. Assim, buscava-se com cada um dos modelos demonstrar que o desenvolvimento era maior conforme o sistema utilizado, motivo pelo qual os teóricos apresentavam estratégias para o desenvolvimento econômico a partir de políticas tidas como corretas, para que fosse adotadas para os países em desenvolvimento, que, na época, ainda eram chamados de terceiro mundo.

A partir de 1989, com as mudanças sociopolíticas ocorridas, notadamente o fim do regime comunista, a fragmentação da União Soviética e a unificação alemã, os estudos em torno do desenvolvimento tornaram-se mais frequentes. Batista (1994) destaca que, em novembro daquele ano, realizou-se uma reunião em Washington para debater políticas desenvolvimentistas para a América Latina. Em seguida, o mesmo autor faz críticas ao modelo adotado:

Em novembro de 1989, reuniram-se na capital dos Estados Unidos funcionários do governo norte-americano e dos organismos financeiros internacionais ali sediados - FMI, Banco Mundial e BID - especializados em assuntos latinoamericanos. O objetivo do encontro, convocado pelo Institute for International Economics, sob o título 'Latin American 
Adjustment: How Much Has Happened?', era proceder a uma avaliação das reformas econômicas empreendidas nos países da região. Para relatara experiência de seus países também estiveram presentes diversos economistas latinoamericanos. Às conclusões dessa reunião é que se daria, subseqüentemente, a denominação informal de 'Consenso de Washington'.

\section{$[\ldots]$}

A disputa ideológica Leste-Oeste, maniqueistamente travada entre modelos estereotipados do capitalismo à la Ronald Reagan e o comunismo stalinista, inviabilizaria a discussão racional e mais serena de alternativas importantes, em particular de outras modalidades de economia de mercado, como as praticadas na Europa ocidental e no Japão. O colapso do comunismo na Europa central e a desintegração da União Soviética, somados à adesão do socialismo espanhol e francês ao discurso neoliberal, facilitaria a disseminação das propostas do Consenso de Washington e a campanha de desmoralização do modelo de desenvolvimento, inspirado pela Cepal, que se havia montado na América Latina sobre a base de capitais privados nacionais e estrangeiros e de uma participação ativa do Estado, como regulador e até empresário.

Com a queda do Muro de Berlim, fez-se leitura simplificada do significado do fim da guerra fria, constatando-se precipitadamente a emergência de nova ordem internacional, uma definitiva Pax Americana, à qual seria inevitável ajustarse. Aceita-se a proclamação do fim da História, com a vitória da economia de mercado e da democracia.

As premissas teóricas do consenso acabaram inspirando uma série de medidas econômicas no Brasil, as quais acabaram por culminar no Plano Real, que estabilizou a economia a partir de 1994 e acabou contribuindo para um processo de desenvolvimento acentuado que atualmente coloca o país como a sexta maior economia mundial. Não obstante ser reconhecido o desenvolvimento nesse período, parecenos que ele se aproxima mais da linha de pensamento mencionada anteriormente, que identifica o desenvolvimento com crescimento 
econômico. Nesse contexto, é preciso verificar se essa linha adotará também as premissas da segunda linha de pensamento, que prega o desenvolvimento com respeito aos direitos humanos e outros valores modernos, como o ambiental. Além disso, é importante também salientar que as instituições no Brasil ainda estão se afirmando, e tal processo é fundamental para se atingir o desenvolvimento com sustentabilidade. Shirley $(2008$, p. 627) ressalta a importância das instituições para o desenvolvimento:

Cross-country regressions are poor tools to determine which particular institutions are necessary for a country to develop: we lack good aggregate measures of complex institutions or an understanding of how these institutions interact with specific country characteristics. Growth regressions have, nevertheless, suggested some important empirical regularities. First, whatever these institutional variables are measuring, they typically explain a sizeable fraction of economic growth. Second, institutions that increase political competition and civil liberties and promote cooperation have a statistically significant and positive association with per capita growth rates and income levels. This fits nicely with the finding of some of the historical studies reviewed earlier that high quality institutions today are rooted in greater equality, political competition and cooperative norms in the distant past.

Schapiro (2011, p. 342) critica, em parte, as reformas plasmadas com base no consenso de Washington, pois não existe uma fórmula uniforme, uma receita única para o desenvolvimento, e a adoção das premissas fundamentais do consenso muitas vezes não levaram ao objetivo pretendido:

[...] as estratégias de organização econômica centradas no protagonismo do Estado e na defesa dos interesses nacionais caíram em desuso no rol de políticas consideradas corretas, muito embora tenham alicerçado o crescimento de boa parte dos países da periferia e da semiperiferia, nas décadas de 1960 e 1970. De 1990 em diante, as recomendações para a abertura da economia assumiram o papel de timoneiro 
seguro para transição dos países até patamares ótimos de desenvolvimento. Bastava aos países mais empobrecidos que eliminassem as barreiras tarifárias e não tarifárias, controlassem o déficit público, diminuíssem o tamanho do setor produtivo estatal, por meio de privatizações, e os mais resultados verificadas na década de 1980 , supostamente atribuídos ao fracasso das políticas de substituição de importações, seriam plenamente equacionados.

O problema está na falta de instituições sólidas. Essas reformas também devem ser baseadas em reformas institucionais que "dariam suporte a uma economia aberta e de fluxo comercial irrestrito". Essas instituições possuíam um padrão pré-determinado, "uma fórmula de tipo one size fits all' (SCHAPIRO, 2011, p. 342).

Para tanto, parte dos estudiosos entende que o Direito exerce um papel importante para o desenvolvimento, gerando um movimento denominado "Direito e desenvolvimento", representado pela máxima do rule of law. Trebilcock e Davis (2009) destacam que esse movimento tem uma longa história, tendo iniciado nos séculos XVIII e se desenvolvido nos seguintes, mas existem traços indicando essa preocupação também na época da colonização. Eles destacam que o "pano de fundo intelectual desse movimento está no período do pós-guerra, que assistiu a um aumento no número de acadêmicos e formuladores de políticas interessados pelas nações pobres do mundo". Esse pensamento deu origem à teoria da modernização:

Os teóricos da modernização afirmavam que o subdesenvolvimento de uma sociedade era causado pelas características ou estruturas econômicas, políticas, sociais e culturais tradicionais (em oposição a modernas) e se refletia nelas. Para progredirem, as sociedades subdesenvolvidas teriam de passar pelo mesmo processo de evolução do tradicionalismo para a modernidade que as sociedades mais desenvolvidas haviam experimentado anteriormente. Porém, enquanto o ímpeto de modernização nos países agora desenvolvidos resultara de mudanças endógenas, a transformação das nações em desenvolvimento resultaria principalmente de estímulos exógenos. Ou seja, 
a modernização do Terceiro Mundo seria realizada pela difusão do capital, das instituições e dos valores do Primeiro Mundo.

Mais especificamente, isso implicaria a emergência de um sistema de livre mercado, do império do direito, de uma política multipartidária, da racionalização da autoridade e do crescimento da burocracia e da proteção dos direitos humanos e das liberdades básicas. [...]

Influenciada por Weber, uma forma concepção instrumentalista do direito estava na base dessa visão da relação entre direito e desenvolvimento. Tal como definida por Burg, essa concepção 'considera o direito uma força que pode ser moldada e manipulada para alterar o comportamento humano e alcançar o desenvolvimento'. (TREBILCOCK; DAVIS, 2009, p. 222)

Corroborando com essa posição, Shapiro (2010) destaca que tal preocupação com a relação entre Direito e desenvolvimento aumentou na década de 1990, destacando que os Estados e as agências multilaterais passaram a estudar com maior atenção o ambiente institucional:

Este entendimento em torno do ambiente institucional e da sua relevância para a promoção dos mercados tem consolidado um novo paradigma no campo da economia política do desenvolvimento - a noção de Rule of Law, um conjunto definido de concepções econômicas, interpretações jurídicas e estratégias políticas para a promoção do crescimento e da modernização econômicas das nações (TRUBEK; SANTOS, 2006). No caso da estratégia Rule of Law, esta convergência entre ideias econômicas, noções de direito e estratégia política está associada a um determinado modelo de desenvolvimento econômico, que é baseado em transações privadas, mediadas pelas garantias jurídicas de proteção à propriedade privada e aos termos contratuais, e, ainda, é vinculado a um viés definido de políticas públicas, em que prevalece a relação Estadoeconomia comprometida com a preservação dos mercados como espaços de alocação de recursos.

No âmbito das ideias econômicas, a concepção prevalecente que informa esse paradigma provém de uma apropriação 
dos estudos da Nova Economica Institucional (NEI), escola oriunda da revisão interna dos cânones da teria econômica matriz neoclássica, que introduziu as instituições como uma variável da análise econômica. (SCHAPIRO, 2010, p. 216217)

Essas lições apontam para o crescimento do papel do Direito na Economia, como lecionam Carvalho e Saddi (2005, p. 11):

Em que pesem as diferenças de ponto de vista, há um amplo reconhecimento entre os economistas de que as leis, o Judiciário e o direito em geral exercem um papel essencial na organização da atividade econômica. Esse reconhecimento, ainda relativamente recente, se deu em larga medida com a melhor compreensão do papel das instituições na economia e, em especial, no desenvolvimento econômico, processo que ganho corpo na década de 1990. North e Olson, por exemplo, apontam as instituições como o determinante mais importante (junto com as políticas econômicas adotadas) do sucesso de um país em desenvolver-se. Segundo Olson, "qualquer país pobre que implemente políticas econômicas e instituições relativamente adequadas experimenta um rápida retomada do crescimento'. Scully obtém evidências empíricas de que países com boas instituições são duas vezes mais eficientes e crescem três vezes mais rápido do que aqueles com instituições ruins.

Portanto, a adoção de políticas econômicas desenvolvimentistas não pode ocorrer de forma isolada. Elas devem ser implementadas juntamente com uma ampla reforma institucional.

\subsection{O desenvolvimento regional no Brasil}

A dimensão do Brasil faz surgir um problema quanto ao desenvolvimento uniforme, impedindo a adoção de políticas que possam ser aplicadas em todo o país. As diferenças econômicas e sociais entre as regiões Sul, Sudeste, Norte e Nordeste são enormes, o que justifica, em parte, a adoção de políticas desenvolvimentistas regionalizadas, com vários incentivos fiscais destinados a apenas algumas áreas e 
a adoção de políticas pelos Estados conhecida popularmente como "guerra fiscal".

Não obstante esse quadro, constitucionalmente, existem várias previsões que tratam do desenvolvimento. Inicialmente, 0 art. $3^{\circ}$ estabelece como um objetivo fundamental da República a garantia ao desenvolvimento nacional e a redução das desigualdades regionais. À União compete a elaboração e execução de planos regionais de desenvolvimento econômico e social (art. 21), além da competência concorrente com Estados, Distrito Federal e Municípios para a fixação de normas que permitam a cooperação entre os entes públicos, visando garantir o equilíbrio do desenvolvimento e do bem-estar em âmbito nacional (art. 23).

A norma constitucional ainda estabelece a possibilidade da articulação em torno de um mesmo complexo geoeconômico e social, visando ao seu desenvolvimento e à redução das desigualdades regionais, cabendo à legislação complementar dispor sobre em que condições será promovida a integração das regiões em desenvolvimento, bem como os organismos que executarão os planos regionais e nacionais de desenvolvimento econômico e social (art. 43).

Para implementar todos esses dispositivos de cunho programático, é permitida a concessão de incentivos regionais na forma de igualdade de tarifas, fretes, seguros e outros itens de custos e preços de responsabilidade do Poder Público; juros favorecidos para financiamento de atividades prioritárias; prioridade para o aproveitamento econômico e social dos rios e das massas de água represadas ou represáveis nas regiões de baixa renda, sujeitas a secas periódicas e, finalmente, para o objeto de estudo neste artigo, isenções, reduções ou diferimento temporário de tributos federais devidos por pessoas físicas ou jurídicas. Nesse contexto se inserem os incentivos fiscais regionalizados, dos quais se destacam aqueles concedidos para a Zona Franca de Manaus.

Em um círculo vicioso, mas não virtuoso, os Estados contraatacam com incentivos fiscais que acabam sendo repelidos por outros estados através de novos incentivos, e assim sucessivamente. 
Infelizmente, o Poder Legislativo, embora tenha competência para legislar a respeito de planos e programas nacionais, regionais e setoriais de desenvolvimento, bem como estudar através de suas comissões esses planos e emitir pareceres (art. 58), omite-se e não se propõe a resolver ou fornecer mecanismos de solução para os incentivos fiscais e as distorções causadas. Até mesmo as instituições de crédito públicas são constitucionalmente estimuladas a financiar as regiões Norte, Nordeste e Centro-Oeste (art. 159 e 163).

No plano tributário, veda-se expressamente à União instituir tributo que não seja uniforme em todo o território nacional ou que implique distinção ou preferência em relação a Estado, Distrito Federal ou Município em detrimento de outro. Porém, ao mesmo tempo, fornece a válvula de descompressão ao admitir a concessão de incentivos fiscais destinados a promover o equilíbrio do desenvolvimento socioeconômico entre as diferentes regiões do país (art. 151).

Assim, a pretexto de um suposto equilíbrio, são concedidos incentivos e benefícios para diferentes regiões, causando impactos em outras, porque as empresas mudam de Estado atrás desses benefícios, continuando a produzir o mesmo produto, mas pagando menos impostos.

Por fim, a norma constitucional estabelece a possibilidade de intervenção do Estado na economia, visando incentivar e planejar o desenvolvimento nacional equilibrado, o qual incorporará e compatibilizará os planos nacionais e regionais de desenvolvimento, conforme adiante exposto.

\section{Intervenção do estado na ordem econômica}

A ordem econômica no Brasil é disciplinada por um conjunto de princípios estabelecidos no art. 170 da Constituição Federal de 1988. Funda-se na valorização do trabalho humano e na livre iniciativa, com o objetivo de garantir a todos os indivíduos uma existência digna, conforme os preceitos da justiça social. Isso significa que a Constituição consagra uma economia de natureza capitalista que prioriza a justiça social sobre 
todos os demais valores da economia de mercado. Essa prioridade tem o sentido de orientar a intervenção do Estado na ordem econômica.

Por isso, a ideia de intervenção é contemporânea à de Estado, pois sempre que este produz normas jurídicas, há um ato de intervenção. A intervenção pode ser definida, então, como a ação do Estado do domínio econômico, buscando, no exercício de sua função, alcançar determinados fins. Opera-se no plano da atividade econômica, consistindo tanto na prática de atos materiais como na produção de atos normativos (GRAU, 2008, p. 146-147).

Eros Roberto Grau (2008, p. 147) distingue a intervenção do Estado no domínio econômico em três categorias: (i) por absorção ou participação, (ii) direção e (iii) indução. A primeira hipótese representa uma intervenção no domínio econômico, ou seja, no âmbito de atividades econômicas em sentido estrito, atuando o Estado em regime de monopólio (intervenção por absorção) ou de competição (intervenção por participação).

Nos casos de intervenção direta por direção e por indução, o Estado intervirá sobre o domínio econômico desenvolvendo sua ação como regulador da economia. Quando faz por direção, o Estado exerce pressão sobre a economia, definindo mecanismos de comportamento compulsórios para os sujeitos da atividade econômica em sentido estrito. Quando o faz por indução, o Estado manipula os instrumentos de intervenção em consonância e na conformidade das leis que regem o funcionamento dos mercados (GRAU, 2008, p. 147).

No art. 174 da CF/1988, está contida a previsão de que o Estado, cumprindo seu papel de agente normativo e regulador da ordem econômica, deverá exercer as funções de fiscalização, incentivo e planejamento. Nos casos das normas de intervenção por direção, se está diante de comandos impositivos de certos comportamentos a serem necessariamente cumpridos pelos agentes que atuam no campo da atividade econômica em sentido estrito. Norma típica de intervenção por direção é a que instrumenta controle de preços (GRAU, 2008, p. 148). 
Nos casos das normas de intervenção por indução, os preceitos, embora prescritivos, não são dotados da mesma carga de cogência que afeta as normas anteriores. Há normas de intervenção por indução quando, por exemplo, o Estado onera por imposto o exercício de certo comportamento, tal como na importação de alguns bens. A indução pode ser positiva quando estimula certa prática; ou negativa se, ao contrário, desestimula dados comportamentos (GRAU, 2008, p. 148-149).

É no campo da intervenção por indução que o Estado pode valerse da política fiscal para alcançar finalidades específicas. Os incentivos fiscais, por exemplo, são largamente utilizados no Brasil, haja vista a política de desenvolvimento do Norte e Nordeste do Brasil (Zona Franca de Manaus, por exemplo) e de certos setores econômicos (produção de biodiesel $^{2}$, por exemplo).

\subsection{Extrafiscaldade}

Além da função arrecadatória, os tributos apresentam funções de estímulo ou desestímulo de certas condutas ou atividades. Nas palavras esclarecedoras de Paulo de Barros Carvalho (2009, p. 254-255):

Fala-se em fiscalidade sempre que a organização jurídica do tributo denuncie que os objetivos que presidiram a sua instituição, ou que governam certos aspectos da sua estrutura estejam voltados ao fim exclusivo de abastecer os cofres públicos, sem que outros interesses - sociais, políticos ou econômicos - interfiram no direcionamento da atividade impositiva. A experiência jurídica nos mostra, porém, que vezes sem conta a compostura da legislação de um tributo vem pontilhada de inequívocas providencias no sentido de prestigiar certas situações, tidas como social, politica ou economicamente valiosas, às quais o legislador dispensa tratamento mais confortável ou menos gravoso. A essa forma de manejar elementos jurídicos

2 Incentivos foram definidos nos Decretos 5.297, de 06 de dezembro de 2004, o qual dispõe sobre os coeficientes de redução das alíquotas da Contribuição para o PIS/PASEP e da COFINS incidentes na produção e na comercialização de biodiesel. 
usados na configuração dos tributos, perseguindo objetivos alheiros aos meramente arrecadatórios, dá-se o nome de extrafiscalidade.

Para Roque Carrazza (2009, p. 116), a extrafiscalidade ocorre quando o "legislador, em nome do interesse coletivo, aumenta ou diminui as alíquotas e/ou as bases de cálculo dos tributos, com o objetivo principal de induzir contribuintes a fazer ou deixar de fazer alguma coisa".

Em consequência, os tributos podem, em função de seu caráter extrafiscal, ser direcionados para a redução de desigualdades sociais e para a regulação ${ }^{3}$ de mercados. Assim, seja pela instituição de tributos ou pela adoção de incentivos fiscais, "possibilita-se ao Estado intervir sobre o domínio econômico de forma indireta, induzindo a adoção de determinados comportamentos" (ASSUNÇÃO, 2011, p. 102).

Isso ocorre porque, ao lado do poder de instituir impostos, os entes federados possuem, também, o poder de desonerar, ou seja, de reduzir o ônus tributário por meio da concessão de benefícios fiscais. Com efeito, a aptidão para tributar alberga também a faculdade de diminuir a carga tributária ou mesmo suprimi-la (CARRAZZA, 2009, p. 861).

Cabe ressaltar, porém, que a alocação mais eficiente dos recursos ocorre pelo livre funcionamento do mercado, e não pela intervenção do Estado. Todavia, apesar de o mercado ser o melhor local para se obter a eficiência alocativa ótima, não raro apresenta falhas. Somente na presença destas deve haver a intervenção estatal, mas ainda assim de forma pontual e específica, a fim de eliminá-las (RIBEIRO, 2009, p. 79).

De todo modo, a extrafiscalidade abre uma importante perspectiva de intervenção estatal na ordem econômica, com o poder de incentivar ou desincentivar certas atividades ou setores econômicos. A utilização dessa competência pode alterar, contudo, o preço relativo dos bens,

\footnotetext{
3 A regulação é a forma como se tenta lidar com as falhas de mercado e aproximar a economia da situação que prevaleceria em concorrência perfeita (PINHEIRO; SADDI, 2005, p. 61).
} 
para o bem ou para o mal, já que modifica as condições naturais do mercado. Por isso, o Estado deve implementar suas políticas com o mínimo de efeitos negativos para a sociedade (CALIENDO, 2009, p. 103). Segundo aduz, "a ofensa a estas premissas implica a ineficiência geral do sistema econômico". O tributo (ou sua desoneração) deve, por conseguinte, ser o mais neutro possível, de forma que não se constitua em elemento importante de decisão do agente econômico nas suas escolhas de investimento (CALIENDO, 2009, p. 117).

\subsection{Princípio da neutralidade da tributação}

Os incentivos fiscais, como já foi dito, também podem impactar negativamente a ordem econômica. As empresas detentoras de benefícios fiscais atuam de forma privilegiada em relação aos seus concorrentes, na medida em que a menor carga tributária afeta decisivamente a formação do preço de seus produtos ou serviços. Por isso, benefícios tributários podem distorcer o sistema econômico, sendo óbices ao desenvolvimento das organizações econômicas não albergadas pela sua concessão. Nesse sentido, "a neutralidade fiscal pode ser vista como um dever dirigido ao Estado, no sentido de que nem a imposição, nem a exoneração tributária causem desequilíbrios na concorrência" (LIMA, 2011, p. 73). A neutralidade fiscal exige, portanto, que a tributação impacte minimamente o preço final dos produtos e serviços postos à disposição no mercado (FORTES; BASSOLI, 2010, p. 243).

Essa neutralidade tributária foi erigida ao status de princípio constitucional explícito com a publicação da Emenda Constitucional $n^{\circ}$ 42, de 19 de dezembro de 2003, que inseriu o art. 146-A na Constituição Federal de 1988. Segundo essa disposição, "Lei complementar poderá estabelecer critérios especiais de tributação, com o objetivo de prevenir desequilíbrios da concorrência, sem prejuízo da competência de a União, por lei, estabelecer normas de igual objetivo".

Como observa Oksandro Gonçalves (2012, p. 88), tal princípio orienta a edição de normas tributárias, reconhecendo a existência de 
uma interface entre tributação e concorrência, haja vista que o tributo pode gerar uma assimetria concorrencial. Completa o referido autor que o Estado tem um papel fundamental no controle da livre concorrência, a qual pode ser prejudicada pela tributação, como expressamente reconhecido no dispositivo em tela, que também pode acontecer com a adoção de incentivos fiscais.

Marco Aurélio Greco (2004, p. 39) destaca que a distorção pode ocorrer de duas formas: a) em razão de as leis fiscais gerarem distorções ou desigualdades num mesmo setor; b) se as leis estiverem adequadamente formuladas, mas sua aplicação concreta não fizer com que sua potencialidade total se efetive.

Vale ressaltar, contudo, que a impossibilidade de a lei tributária gerar desequilíbrios concorrenciais já se encontrava implícita na Constituição, nos artigos 150, II, 150, 6 e 152. O art. 146-A veio tão somente explicitar a regra da neutralidade tributária, atribuindo ao Estado dois tipos de deveres: um positivo e o outro negativo. O negativo, no sentido de que a política fiscal não deve intervir no mecanismo concorrencial no qual já existe uma concorrência (quase) perfeita; o positivo, quando parecer conveniente ao Estado adotar uma política fiscal que vise fomentar a concorrência à medida que a livre concorrência for imperfeita (ROTHMANN, 2009, p. 341).

No seu aspecto negativo, pode-se afirmar que o princípio da neutralidade fiscal é uma verdadeira limitação ao poder de tributar. 0 respeito a esse princípio viabiliza os princípios da livre concorrência e da livre iniciativa, que preservam de modo saudável as trocas econômicas e, por conseguinte, o desenvolvimento nacional, como, aliás, determina o inc. II, do art. $3^{\circ}$, da Constituição Federal de 1988.

Importante ainda observar que a neutralidade fiscal é verificável sob três perspectivas: enquanto igualdade de condições no jogo de mercado; enquanto ausência de barreiras estatais de ingresso e permanência no mercado; e enquanto interferência nula ou mínima do Estado no jogo de mercado (FORTES; BASSOLI, 2010, p. 241). 
Pela primeira perspectiva (igualdade de condições), tem-se que a tributação deve ser regulamentada de tal forma que não cause desigualdades entre aqueles que se encontram sob a mesma situação jurídica. Tércio Ferraz Jr. (2005, p. 733-734), no mesmo sentido, aduz que a neutralidade fiscal, sob a perspectiva da igualdade, será ferida quando:

[...] ficar demonstrado que, por lei, as relações competitivas entre empresas concorrentes em igualdade de condições venham a ser restringidas por uma medida (legal) que efetivamente crie para elas uma diferença que passe a existir apenas em virtude da própria medida.

Hamilton Dias de Souza (2006) assevera que o Estado, ao instituir um determinado tributo, não pode afetar a livre concorrência:

No campo tributário, a neutralidade dos tributos em face da atividade econômica decorre, em especial, da proibição de tratamento desigual entre contribuintes e da exigência de respeito à sua capacidade contributiva. É óbvio que qualquer medida impositiva de natureza tributária interfere na capacidade competitiva dos concorrentes. Assim, o princípio da isonomia será ferido se as relações concorrenciais entre empresas forem afetadas pela tributação, de tal modo que esta favoreça/desfavoreça umas em face de outras.

No mesmo sentido, Scaff (2006, p.78):

Um dos requisitos para o exercício da livre-concorrência, que, como vimos, tem por bem primordial o Princípio da Isonomia, é que os tributos sejam economicamente neutros para que não venham a distorcer os preços praticados pelas empresas dentro de um mesmo mercado relevante. Tratase do Princípio da Neutralidade Econômica dos Tributos, que impede que este tipo de "intervenção econômica" do Estado cause desequilíbrios concorrenciais.

O Princípio da Neutralidade Econômica dos Tributos pode ser encontrado em nosso sistema jurídico a partir do Princípio da Isonomia Fiscal (art. 150, II, da CF) que veda 
ao Poder público o tratamento desigual entre contribuintes que se encontrem em situação equivalente, o que alcança, sem a menor sobra de dúvida, os aspectos concorrenciais.

Porém, cabe destacar que inexiste qualquer violação à neutralidade fiscal, sob a perspectiva ora abordada, no caso de a legislação tributária atribuir tratamento diverso a contribuintes que se encontrem em situações econômicas diversas. Como exemplos, podem ser citados os artigos 146, III, d, e 170, IX, da Constituição Federal, que preveem tratamento tributário diferenciando para as micro e pequenas empresas. Portanto, "salvo para nivelar desigualdades inerentes aos próprios agentes econômicos, à tributação é vedado causar desequilíbrios na livre concorrência" (FORTES; BASSOLI, 2010, p. 242). Nesse ponto, destaca-se o princípio da igualdade, que, na perspectiva de Celso Antonio Bandeira de Mello (1997, p. 21-22), permite um tratamento discriminatório, desde que os valores constitucionais sejam harmonizados:

Esclarecendo melhor: tem-se que investigar, de um lado, aquilo que é adotado como critério discriminatório; de outro lado, cumpre verificar se há justificativa racional, isto é, fundamento lógico, para, à vista do traço desigualador acolhido, atribuir o específico tratamento jurídico construído em função da desigualdade proclamada. Finalmente, impende analisar se a correção ou fundamento racional abstratamente existente é, in concreto, afinado com os valores prestigiados no sistema normativo constitucional. A dizer: se guarda ou não harmonia com eles.

Marcel Bragança (2001, p. 145), ao analisar a teoria de Ronald Coase a respeito dos custos de transação e das externalidades negativas, leciona que a tributação pode ser um óbice para a competitividade empresarial:

Embora a teoria em foco analise as externalidades criadas entre os agentes de mercado o exemplo da forma da tributação do setor elétrico demonstra as 'externalidades' que são criadas pelo direito tributário em relação ao direito 
concorrencial e do consumidor, afetando, em última análise, a própria sociedade. Os objetivos pretendidos pela tentativa de criação de um ambiente competitivo são frustrados ou encontram óbice devido à forma de tributação.

Portanto, essa norma encerra um princípio que deve orientar o sistema tributário nacional, reconhecendo a possibilidade de um tributo influenciar na concorrência empresarial.

Pela segunda perspectiva da neutralidade fiscal, a tributação não pode impor barreiras para as empresas ingressarem ou permanecerem no mercado. A proibição de barreiras é conduta também amparada pela Lei $n^{\circ} 12.529 / 2011$, que em seu art. 36 tipifica como infração à ordem econômica nacional limitar ou impedir o acesso de novas empresas ao mercado e criar dificuldades à constituição, ao funcionamento ou ao desenvolvimento de empresa concorrente ou de fornecedor, adquirente ou financiador de bens ou serviços (FORTES; BASSOLI, 2010, p. 243).

No contexto da nova legislação da concorrência, destaca-se o papel da Secretaria de Acompanhamento Econômico (SEAE), a quem cumpre promover a concorrência em órgão do governo (art. 19). Dentre suas atribuições, estão: opinar acerca de proposições legislativas em tramitação no Congresso Nacional que possam afetar a concorrência; avaliar setores específicos da atividade econômica nacional (por exemplo, mercado de bebidas frias); elaborar estudos setoriais para a formulação de políticas públicas; e os mais importantes:

propor a revisão de leis, regulamentos e outros atos normativos da administração pública federal, estadual, municipal e do Distrito Federal que afetem ou possam afetar a concorrência nos diversos setores econômicos do País e encaminhar ao órgão competente representação para que este, a seu critério, adote as medidas legais cabíveis, sempre que for identificado ato normativo que tenha caráter anticompetitivo.

Sendo assim, é possível que a SEAE, órgão do Sistema Brasileiro de Defesa da Concorrência (SBDC), ao constatar que uma 
norma tributária está afetando a concorrência num determinado setor, proponha alterações que possam restabelecer a concorrência equitativa entre os agentes econômicos envolvidos.

Nessa linha, afirma Ferraz Júnior (2005, p. 732) que o "princípio da neutralidade concorrencial deriva diretamente da liberdade de iniciativa, seja no sentido de acesso ao mercado, seja no de livre conformação e disposição da atividade econômica", tanto que, nas normas que regulam a concorrência no Brasil, há previsão legal permitindo a adoção de medidas contra normas que produzam resultados anticompetitivos, ainda que sejam de cunho tributário. Destarte, é certo que a norma pode produzir um resultado danoso à concorrência, de forma direta ou indireta, servindo de campo próprio para o estudo da AED.

Pela última perspectiva, o preço do bem ou do serviço deve ser ajustado de acordo com o jogo de mercado, sem qualquer interferência dos concorrentes ou de terceiros. Cabe ao Estado tão somente adotar ações positivas no sentido de coibir as externalidades causadas pelo próprio regime de produção, fiscalizando, incentivando ou planejando as atividades econômicas quando assim se fizer necessário (FORTES; BASSOLI, 2010, p. 243). A neutralidade concorrencial garante a igualdade de chances para os agentes econômicos, o que significa que o Estado deve abster-se de medidas que, ao privilegiar concorrentes em igualdade de condições, venham a prejudicar consumidores ou desfavorecer pequenas empresas (FERRAZ JR., 2005, p. 732-733).

Em suma, o princípio da neutralidade fiscal trabalha no sentido de evitar, ou diminuir, os efeitos da tributação sobre a decisão dos agentes econômicos. Pressupõe o entendimento de que o uso de certas políticas pode significar a procura de um diferente equilíbrio para a economia. Nesse contexto, para a intervenção estatal na ordem econômica ser válida, por meio de políticas tributárias, ela deve respeitar, entre outros valores consubstanciados no art. 170 da CF/1988, a livre iniciativa e a livre concorrência (FORTES; BASSOLI, 2010, p. 240).

Hamilton Dias de Souza (2006) destaca a influência do tributo na competição entre empresas: 
É inegável a influência do tributo na competição entre as empresas pela conquista de mercado, cujo sucesso dependerá, dentre outros fatores, do aumento da sua eficiência tributária que, por sua vez, implicará melhor condição de competir.

Por derradeiro, cabe destacar que o princípio em análise une, definitivamente, tributo e economia, havendo uma limitação ao poder de tributar se a política tributária afetar a neutralidade concorrencial. Nessa perspectiva, Fortes e Bassoli (2010, p. 246) afirmam

que a instituição e a construção da regra-matriz de incidência tributária dos tributos estão, agora, expressamente vinculadas aos preceitos econômicos", de modo que, conforme ditames da Análise Econômica Normativa do Direito, "o Direito Tributário tem suas competências e regras plenamente vinculadas aos preceitos econômicos, sendo destes indissociáveis.

\subsection{Incentivos fiscais}

Como visto, a extrafiscalidade pode ser aplicada pelo mecanismo da concessão de incentivos fiscais, os quais se afirmam como instrumentos indutores de comportamentos direcionados ao alcance de objetivos definidos constitucionalmente. Em função disso, sua utilização deve estar em sintonia com a busca do bem comum, ditando-se por considerações de interesse coletivo (BORGES, 2007, p. 70-71).

Na realidade, como preconiza Odair Tramontin (2002, p. 111-112), a concessão de incentivos fiscais representa uma concretização da intervenção do Estado na economia, devendo ser compreendidos como norma jurídica de direção econômica a serviço do desenvolvimento de interesse do país ou de determinada região ou setor da economia. É, com efeito, uma manifestação de dirigismo estatal através da intervenção do Estado na iniciativa privada para estabelecer os rumos da economia.

Por isso, os incentivos fiscais, como importantes mecanismos de intervenção do Estado na ordem econômica, têm ampla previsão 
constitucional, estando estabelecidos em diversas disposições do texto constitucional, como nos artigos 174, 151, I, 43, §2 ${ }^{\circ}$ III e 150, §6.

Ademais, podem os incentivos fiscais assumir roupagens diversas, como isenções, reduções de alíquotas e/ou bases de cálculo, anistia, moratória, remissão, concessão de créditos tributários, diferimento do pagamento de tributos, créditos presumidos, alíquotas zero, entre outros. Nessa perspectiva, pode ser considerado incentivo fiscal qualquer instrumento, de caráter tributário ou financeiro, com o objetivo de realizar finalidades constitucionalmente previstas, através da intervenção estatal por indução. Essas vantagens podem operar subtrações ou exclusões no conteúdo de obrigações tributárias, ou mesmo adiar os prazos de adimplemento dessas obrigações. É possível, ainda, que autorizem transferências diretas destinadas a cobrir despesas de custeio das entidades beneficiadas, como acontece com as subvenções, previstas no art. 12, $\S 3^{\circ}$, da Lei ${ }^{\circ} 4.320 / 64$ (ASSUNÇÃO, 2011, p. 107). Carrazza (2009, p. 496), no mesmo sentido, informa:

Os incentivos fiscais manifestam-se sob a forma de imunidades tributárias, de isenções tributárias, de remissões tributárias, de parcelamento de débitos tributários etc. Exceção feita ao caso de imunidade, os incentivos fiscais que se traduzem em mitigações ou supressões da carga tributária só são válidos se forem criados pela pessoa jurídica competente para tributar.

Não cabe aqui analisar cada um desses tipos de incentivos fiscais. O que deve ser observado é que a gama de possibilidades de concessão de benefícios fiscais é enorme e vem sendo utilizada grandemente em todos os níveis da Federação. Cabe ressaltar, ainda, que eles devem apenas ser concedidos na busca de soluções para os problemas econômicos, sociais (correções de falhas de mercado) e desigualdades regionais. Mas, mesmo nesses casos, deve sempre haver a indicação dos beneficiários, a finalidade da concessão, as condições para a fruição, o prazo da vigência e o montante dos benefícios concedidos. É indispensável também que, após a concessão dos benefícios, o Poder Público faça uma adequada fiscalização para aferir a sua aplicação 
em prol da recuperação econômica regional ou setorial (TRAMONTIN, 2002, p. 111), ou seja, se os fins para os quais foram instituídos estão sendo efetivamente atingidos.

Por derradeiro, cabe destacar que a concessão de incentivos fiscais pelos Estados-membros e Distrito Federal relativamente ao ICMS deve ser submetida à aprovação do Conselho Nacional de Política Fazendária (CONFAZ). Busca-se, com isso, evitar que as unidades da Federação utilizem os incentivos fiscais como meios de atrair investimentos em desrespeito aos interesses nacionais. O objetivo é, pois, evitar os efeitos danosos das práticas conhecidas como "guerra fiscal".

\subsection{Guerra fiscal}

A Constituição de 1988 outorgou a impositiva do ICMS aos Estados e ao Distrito Federal. Porém, subordinou o poder impositivo estadual de concessão de isenções, incentivos e benefícios fiscais em matéria de ICMS ao legislador complementar da União, ao reservar à lei complementar o papel de "regular a forma como, mediante deliberação dos Estados e do Distrito Federal, isenções, incentivos e benefícios fiscais serão concedidos e revogados" (art. 155, §2 ${ }^{\circ}$ XII, g, da CF/1988).

Como se vê, essa disposição excepciona a regra geral que determina que só quem possui competência tributária para instituição de determinado tributo tem também o poder de isentar ou estabelecer qualquer outro benefício fiscal (CARRAZZA, 2009, p. 496). Observa este autor:

Não há, portanto, isenções autonômicas, em matéria de ICMS. Notamos, a propósito, que a lei ordinária (estadual ou distrital) também não pode, no que concerne a este tributo, conceder incentivos e benefícios fiscais (reduções da base de cálculo, créditos presumidos e fictícios, remissões parciais, anistias, diferimentos, parcelamentos de débitos tributários, adiamento de prazos de pagamentos, e assim por diante) (CARRAZZA, 2009, p. 496). 
O dispositivo constitucional mencionado determina, ainda, que a lei complementar pode dispor sobre a forma de deliberação interestadual para a concessão de isenções, incentivos e benefícios fiscais, cujo instrumento jurídico é o convênio. Em outros termos, a lei complementar não poderá estabelecer o conteúdo dos convênios, apenas os mecanismos jurídicos que nortearão sua celebração (CARRAZZA, 2009, p. 497 e 503).

Verifica-se, portanto, que ao legislador complementar não foi outorgado o poder de estabelecer as hipóteses em que as isenções e incentivos fiscais podem ser concedidos pelos Estados, mas apenas o poder de fixar regras para a formalização pelas Assembleias Legislativas dos Estados e do Distrito Federal, com vistas à sua concessão.

Porém, a referida lei complementar ainda não foi elaborada. ${ }^{4}$ Assim, mesmo a Constituição não tendo estabelecido qual o tipo de deliberação seria adotado pelos Estados para possibilitar a outorga de benefícios fiscais, convencionou-se que tais deliberações se dariam sob a forma de convênios, com base no $\S 8^{\circ}$, do art. 34, do ADCT.

Nessa seara, foi recepcionada pelo Texto Supremo, a Lei Complementar $\mathrm{n}^{\circ} 24$, de 7 de janeiro de 1975, que dispõe sobre os convênios para a concessão de isenções do imposto sobre operações relativas à circulação de mercadorias. Ela determina também, no seu art. $2^{\circ}$, que os convênios serão celebrados em reuniões para as quais tenham sido convocados representantes de todos os Estados e do Distrito Federal, dependendo a concessão de benefícios sempre de decisão unânime dos Estados presentes. O colegiado apto a deliberar sobre esses convênios é denominado de Conselho Nacional de Política Fazendária (CONFAZ), integrado por representantes (Secretários da Fazenda) de cada Estado e do Distrito Federal, órgão esse que

Saliente-se que o art. 27 da Lei Complementar 87, de 13/09/1996, que tratava do assunto foi vetado pelo Presidente da República, razão pela qual o assunto continua sob a égide da Lei Complementar n. 24, de 7.1.1975 (CARRAZZA, 2009, p. 503). 
é presidido por um representante do Governo Federal (Ministro da Fazenda).

Os convênios, como observa Carrazza (2009, p. 503), fortalecem a Federação, evitando que cada Estado-membro busque, por intermédio de benesses concedidas unilateralmente, atrair empresas, a qualquer preço, para seus territórios. Portanto, os Estados e o Distrito Federal, querendo conceder isenções de ICMS, devem, previamente, firmar entre si convênios. Não são os convênios, entretanto, que dão força normativa às deliberações tomadas. Estas resultam do decreto legislativo em cada unidade federativa. Assim, o conteúdo dos convênios só passa a valer como direito interno dos Estados e do Distrito Federal depois da ratificação por decreto legislativo. Esse ato normativo é o ponto terminal do processo legislativo adequado à concessão de isenções de ICMS. Não é o convênio, portanto, que concede o benefício fiscal relativo ao ICMS. Ele tão somente permite que o Legislativo de cada Estado e do Distrito Federal o faça (CARRAZZA, 2009, p. 498-499).

O papel fundamental dos convênios é, portanto, evitar que os Estados e o Distrito Federal deliberem isoladamente sobre concessão de benefícios fiscais no âmbito dos seus territórios. Seu objetivo é evitar uma disputa entre os Estados por investimentos empresariais à troca de benesses fiscais.

Entretanto, o desrespeito ao ordenamento jurídico faz com que os Estados e o Distrito Federal travem um verdadeiro embate por investimentos privados com a utilização de mecanismos tributários. A essa disputa dá-se o nome de "guerra fiscal", realizada à revelia do ordenamento jurídico. Ressalte-se, também, que as sanções previstas para o descumprimento das regras estabelecidas na Lei Complementar n. $24 / 75$, dispostas no art. $8^{\circ}$ da mesma lei, são também ignoradas a quem teria competência para determiná-las, o Tribunal de Contas da União. Em suma:

A guerra fiscal é, como o próprio nome indica, uma situação de conflito na Federação. O ente federado que ganha - quando de fato, existe algum ganho - impõe, na maioria dos casos, uma perda a algum 
ou a alguns dos demais, posto que a guerra raramente é um jogo de soma positiva. O federalismo, que é uma relação de cooperação entre as unidades de governo, é abalado. Também a Federação - cara aos brasileiros a ponto de a Constituição conter cláusula pétrea que impede sua abolição - perde. (VARSANO, 1997, p. 6).

A guerra fiscal se trava, como demonstrado, à revelia do ordenamento jurídico e do respeito ao sistema federativo, o que revela uma fraqueza das instituições basilares de um Estado Democrático de Direito. Aliás, a fraqueza das instituições, na lição de Douglas North (1993), é um sério entrave ao desenvolvimento econômico. Para o autor, as instituições formam a estrutura de incentivos de uma sociedade e, portanto, tanto as instituições políticas quanto as econômicas são determinantes fundamentais do desempenho econômico.

Ressalte-se, ainda, que não é apenas no âmbito do ICMS que a guerra fiscal se desenvolve. Em outros impostos, como o Imposto sobre Serviços (ISS) ${ }^{5}$ (de competência municipal) e o Imposto sobre Imposto sobre Propriedade de Veículos Automotores (IPVA) ${ }^{6}$, também há batalhas sendo travadas.

5 Reportagem da Gazeta do Povo, publicada em 05/09/2010, informa que cidades da Região Metropolitana de Curitiba usam o limite mínimo permitido para o ISS como forma de atrair sedes empresariais de fachada para os seus Municípios. Revela, ainda, que estas empresas continuam localizadas em Curitiba e é aí que prestam seus serviços. Cita como exemplo um prédio comercial de quatro andares situado em Mandirituba - PR que abriga mais de 200 empresas, como madeireiras, agências de turismo, consultorias, editoras, produtoras de vídeo, assessorias em comércio exterior e empreiteiras. Na prática, entretanto, apenas uma autoescola, um consultório de dentista e algumas outras poucas atividades comerciais funcionam no prédio. Disponível em: <http://www.gazetadopovo.com.br/economia/conteudo.phtml?id=1043372>. Acesso em: 29 jun. 2012.

$6 \quad$ No que toca ao imposto sobre a propriedade de veículos automotores (IPVA), a guerra fiscal nasce da imposição de diferentes alíquotas pelos diversos Estados da Federação, alguns onerando mais e outros menos a propriedade do veículo automotor situado no seu território. Em regra, os Estados que mais oneram seus contribuintes assistem a uma debandada de contribuintes para os Estados que empregam alíquotas menores. O conflito entre Paraná e São Paulo constitui um caso emblemático, pois as alíquotas praticadas no Paraná são menores do que aquelas praticadas em São Paulo e, tratando-se de Estados vizinhos, muitos proprietários paulistas de veículos automotores buscam refúgio no Paraná, licenciando neste Estado seus veículos. O Paraná, como outros Estados que licenciam veículos de contribuintes alienígenas, não cria empecilhos ao registro, interessado que está na receita do IPVA destes contribuintes. (SIMÕES, 2009, p. 181-182). 
Por essa razão, o Supremo Tribunal Federal propôs a edição da Súmula Vinculante n. 69, com a seguinte redação original:

Qualquer isenção, incentivo, redução de alíquota ou de base de cálculo, crédito presumido, dispensa de pagamento ou outro benefício fiscal relativo ao ICMS, concedido sem prévia aprovação em convênio celebrado no âmbito do CONFAZ, é inconstitucional.

Dessa forma, sem a aprovação unânime dos Estados, não há como prevalecer uma norma que institua tratamento tributário diferenciado através de isenção, incentivo ou qualquer outro mecanismo que possa alterar o ambiente competitivo. Por outro lado, cria-se uma situação não negligenciável para as empresas beneficiadas por incentivos fiscais e para os Estados que os concederam. Elas tomaram decisões em função dos benefícios fiscais concedidos, instalando suas indústrias nos Estados em função principalmente desse fator. Os Estados serão obrigados, pela Súmula Vinculante, caso editada, a cobrar das empresas que usufruíram dos benefícios depois de terem negociado protocolos e convênios. Um novo custo de transação e uma externalidade oriunda de uma decisão judicial.

Sob diversos prismas, é possível destacar os efeitos perversos da "guerra fiscal", que, além da renúncia à arrecadação do tributo, cria um ambiente de concorrência desleal, aumenta a complexidade do sistema tributário e aumenta as externalidades do sistema econômico. Ou seja, o Direito funciona não como uma instituição capaz de diminuir os custos de transação, mas, paradoxalmente, trabalha em seu sentido inverso. Tal situação, por óbvio, altera para pior o ambiente econômico. Pode gerar a dominação de mercado, por causas não naturais, por empresas agraciadas com os benefícios fiscais ou incentivar o deslocamento de agentes econômicos envolvidos no processo produtivo de bens agraciados com o incentivo fiscal para locais onde seus custos de produção e de transporte são maiores. É o que será demonstrado a seguir. 


\section{Estudos de caso: guerra fiscal e Zona Franca de Manaus}

\subsection{O caso dos refrigerantes: Zona Franca de Manaus}

O setor econômico de refrigerantes no Brasil concentra em duas grandes empresas $73 \%$ desse mercado. Ou seja, já existe uma falha de mercado com a existência de empresas com poder econômico. Porém, há outros fatores de desequilíbrios no setor, decorrentes de incentivos fiscais oferecidos na Zona Franca de Manaus (ZFM). Embora tais benefícios fiscais sejam legais, eles têm sido empregados em complexos planejamentos tributários desenvolvidos por empresas de grande porte, com o objetivo de reduzir custos em etapas posteriores à saída do produto dessa região, o que gera um ganho artificial de competitividade e desequilibra a concorrência (GONÇALVES, 2012, p. 73). A instituição da ZFM deu-se através Lei n. 3173/1957 e posteriormente foi regulamentada por vários decretos. ${ }^{7}$ Originariamente, era seu objetivo

armazenar, beneficiar e retirar mercadorias, artigos e produtos de qualquer natureza, provenientes do estrangeiro e destinados ao consumo da Amazônia, como dos países interessados, limítrofes do Brasil ou que sejam banhados por águas tributárias do rio Amazonas. ${ }^{8}$

A preocupação central dessas iniciativas era a criação de uma estrutura de ocupação da imensa região amazônica e sua consolidação como parte efetiva da estrutura federativa do país.

Ataliba (1999, p. 207) sintetiza a expectativa em torno da ZFM, mas salienta que seu principal objetivo foi permitir o desenvolvimento da região amazônica mediante a fixação do homem com a ocupação e atrair capitais para investir e criar indústrias:

1. Quem conheceu o clima político e econômico brasileiro anterior a 1967, sabe a expectativa que cercou a criação da Zona Franca de Manaus, como pólo de desenvolvimento,

Decretos n. 47757/1960, 51114/1961 e 723/1962.

Art. $1^{\circ}$ da Lei n. 3173/1957. 
tendo por objetivo estimular a fixação do homem, atrair capitais, consumir matéria-prima local, criar um centro industrial e econômico-demográfico na região. Com isso, lançaram-se bases e meios propícios ao estabelecimento objetivo de condições concretas, de estável ocupação do território, tendo em vista também a segurança nacional.

Daí o espírito estimulante da vasta e ampla legislação que veio implantar tais objetivos, implicando sacrifícios à União e até a Estados alheios à região, a bem da realização daqueles designíos. O desenvolvimento da Amazônia foi, nesse momento, qualificado, acertadamente, como 'de interesse nacional'.

2. A clara e exata compreensão da occasio e da mens legis deixa evidente que o espírito informador dessa legislação pode ser traduzido no propósito que impregnou toda nação de tudo fazer pelo desenvolvimento da Amazônia.

Essa definição foi ampliada pelo Decreto-Lei n. 288/1967, a fim de torná-la uma

área de livre comércio de importação e exportação e de incentivos fiscais especiais, estabelecida com a finalidade de criar no interior da Amazônia um centro industrial, comercial e agropecuário dotado de condições econômicas que permitam seu desenvolvimento, em face dos fatores locais e da grande distância a que se encontram os centros consumidores de seus produtos.

Foi a partir deste momento que houve a modificação do papel da ZFM, até então um entreposto aduaneiro, para ser um

instrumento de promoção do desenvolvimento regional, visando à integração da Amazônia na comunidade econômica brasileira, através da criação de condições que the assegurem, nessa comunidade, o lugar que the compete em função do pleno emprego de suas capacidades potenciais. (SOUZA, 2006, p.120)

Em 1988, a ZFM ganhou reconhecimento constitucional, sendo mantida "com suas características de área de livre comércio" por 
expressa previsão do art. 40 do ADCT. Após essa breve retrospectiva a respeito da ZFM, importante focar no objeto específico deste trabalho, que é a questão tributária-concorrencial envolvendo os concentrados para a produção de refrigerantes. O art. $9^{\circ}$ do Decreto-Lei $n^{\circ}$ 288/1967, com redação dada pela Lei $n^{\circ} 8.387 / 1991$, estabelece a isenção do IPI para mercadorias produzidas na ZFM. Por tal razão, os concentrados são fabricados pelas maiores empresas do setor de refrigerantes na ZFM, embora, do ponto de vista da racionalidade produtiva, não se justifique a sua produção nesse local, uma vez que se encontra bastante distante das fábricas produtoras de refrigerantes para as quais se destinam (GONÇALVES, 2012, p. 83).

Logo, a justificativa para a escolha do local de fabricação desses concentrados é unicamente de natureza tributária (GONÇALVES, 2012, p. 83-85). Além de isentos, como os concentrados são comercializados com empresas do mesmo grupo fora da ZFM, com a sua aquisição, possibilita-se que essas empresas acumulem créditos tributários. Tal mecanismo de crédito permite que seja reduzido o preço final do produto. Há, por isso, um ganho econômico artificial, gerando maior competitividade em relação aos demais concorrentes que não podem se instalar na ZFM. Pela sistemática estabelecida, a empresa destinatária dos concentrados produzidos pode calcular um crédito presumido de IPI que será descontado do IPI a pagar ou ser ressarcido, caso este se acumule ao fim do período de apuração. Em suma, há com esse mecanismo legal de creditamento de bem isento adquirido um relevante diferencial competitivo. Como a concorrência não consegue produzir os mesmos créditos que as empresas dominantes do mercado, ficam, em consequência, prejudicadas em relação ao preço final do produto. Importante destacar que o mercado de refrigerantes é muito sensível ao fator preço, ou seja, qualquer ganho nesse item, por mínimo que seja, impacta substancialmente nos demais concorrentes. Enfim, a união entre isenção e a possibilidade da transferência dos créditos cria uma anomalia que afeta a concorrência no setor de refrigerantes, diminuindo a margem de competitividade dos pequenos fabricantes regionais. 
Se, por um lado, a norma instituidora da ZFM tem por objetivo promover o desenvolvimento da região amazônica, por outro, gera um custo de transação elevado para os demais concorrentes instalados em Estados que não possuem o mesmo tratamento legal, ocasionando um desequilíbrio concorrencial que pode levar ao fechamento de empresas ou seu deslocamento para outras regiões, contribuindo negativamente para o desenvolvimento regional. Essa externalidade é relevante e não pode ser desconsiderada no momento da formulação de políticas públicas centradas na promoção da concorrência.

Visando corrigir em parte essa distorção, foi editado o Decreto n. 7742 , de 31 de maio de 2012, alterando as alíquotas ad valorem do IPI dos concentrados produzidos na ZFM, os quais passariam a ser de $17 \%$ a partir de outubro de 2012, e 10\% a partir de 2013 . Todavia, no dia 4 de junho, foi publicada uma retificação do referido Decreto para estabelecer que a alíquota passará a ser de $20 \%$ a partir de $1^{\circ}$ de outubro de 2012 , mas não menciona a redução de $10 \%$ na versão anterior. Como se trata de decreto retificador, ele não poderia alterar senão erros materiais, e não as premissas básicas fixadas na norma retificada. Assim, a redução da alíquota que gera o crédito na ZFM, depois transferido na cadeia produtiva, foi insuficiente para impedir o desequilíbrio concorrencial.

É possível concluir, portanto, que os benefícios fiscais concedidos ferem o princípio da neutralidade concorrencial e não são eficientes sob os critérios de Pareto (embora os benefícios melhorem a situação de algumas empresas, suas concorrentes e toda a coletividade perdem) e de Kaldor-Hicks (os ganhos advindos com a instituição do benefício fiscal não compensam suas perdas). Ademais, constata-se facilmente que os benefícios instituídos ampliam as falhas de mercado, pois aumentam o poder econômico das empresas dominantes. Observa-se, ainda, que também aumentam as externalidades negativas, uma vez que estimulam o transporte desses produtos (concentrados) por longas distâncias, viáveis apenas em virtude de benefícios tributários, ou seja, a custo de toda a sociedade. Por isso, a lei que concede os benefícios fiscais analisados é injusta, já que aumenta a ineficiência do sistema 
econômico, gerando desperdícios e perdas de bem-estar para toda a coletividade.

\subsection{O caso dos sabonetes: guerra fiscal}

O Conselho Administrativo de Defesa Econômica (CADE) foi instado a se manifestar, via Consulta elaborada pelo Pensamento Nacional das Bases Empresariais (PNBE), em relação aos aspectos concorrenciais envolvidos na política de incentivos fiscais e financeirofiscais concedidos pelos Municípios e Estado, conhecidos por "guerra fiscal". O PNBE buscou, através da Consulta formulada, questionar se as práticas oriundas da "guerra fiscal" podem ou não ter efeitos na livre concorrência e na livre iniciativa, não fazendo referência a qualquer caso concreto em específico. A tese da Consulente era a de que a empresa beneficiária de incentivos fiscais pode oferecer preços inferiores aos das demais empresas, o que tem a potencialidade de ocasionar o domínio do mercado, bem como ser uma barreira de entrada a novas empresas no setor (BRASIL, CADE, 1999, p. 1).

No voto condutor do Parecer CADE n³9/1999, o Relator afirma, inicialmente, que a forma pela qual ocorre a desoneração tributária do ICMS é indiferente para os fins de sua análise, dado que tanto a concessão de incentivos puramente fiscais como de incentivos financeiro-fiscais têm o mesmo efeito sobre os mercados em que estas atuam. Segundo aponta, qualquer incentivo fiscal ou financeiro-fiscal pode trazer grandes vantagens para as empresas agraciadas (BRASIL, CADE, 1999, p. 3).

O Parecer (BRASIL, CADE, 1999, p. 5-9) analisou, então, tabelas de custos de uma empresa hipotética de sabonetes, baseadas em dados reais organizados pela empresa de consultoria KPMG. Foi possível constatar um expressivo aumento nos lucros unitários, em virtude da existência de incentivos fiscais. Os dados contábeis dessa empresa hipotética revelam a grande importância que o ICMS possui no lucro operacional, constituindo-se, na verdade, como o tributo indireto que mais onera essa produção. O peso considerável do ICMS para a 
lucratividade da empresa fica ainda mais claro na análise das tabelas a seguir, que passam a supor a existência de exonerações do ICMS da ordem de $6 \%, 10 \%$ e $18 \%$, respectivamente. Vejamos:

\begin{tabular}{|c|c|c|c|}
\hline $\begin{array}{c}\text { Alíquotas do } \\
\text { ICMS }\end{array}$ & $\begin{array}{c}\text { Lucro / } \\
\text { Faturamento }\end{array}$ & $\begin{array}{c}\text { Variação do } \\
\text { ICMS }\end{array}$ & $\begin{array}{c}\text { Variação do } \\
\text { Lucro }\end{array}$ \\
\hline $18 \%$ & $2,71 \%$ & $0 \%$ & $0 \%$ \\
\hline $12 \%$ & $6,20 \%$ & $-33 \%$ & $128 \%$ \\
\hline $8 \%$ & $8,54 \%$ & $-56 \%$ & $215 \%$ \\
\hline $0 \%$ & $13,21 \%$ & $-100 \%$ & $388 \%$ \\
\hline
\end{tabular}

Em conclusão, a redução da alíquota do ICMS de 18\% para $0 \%$ faz o lucro da empresa incrementar em incríveis 388\%.

Em outro estudo, demonstrado no mesmo Parecer (BRASIL, CADE, 1999, p. 10-11), relativo à produção de louça sanitária, o CADE, com base em dados também em dados fornecidos pela KPMG, chega aos seguintes resultados:

\begin{tabular}{|c|c|c|c|}
\hline $\begin{array}{c}\text { Alíquotas do } \\
\text { ICMS }\end{array}$ & $\begin{array}{c}\text { Lucro I } \\
\text { Faturamento }\end{array}$ & $\begin{array}{c}\text { Variação do } \\
\text { ICMS }\end{array}$ & $\begin{array}{c}\text { Variação do } \\
\text { Lucro }\end{array}$ \\
\hline $18 \%$ & $5,60 \%$ & $0 \%$ & $0 \%$ \\
\hline $12 \%$ & $9,50 \%$ & $-33 \%$ & $70 \%$ \\
\hline $8 \%$ & $12,20 \%$ & $-56 \%$ & $118 \%$ \\
\hline $0 \%$ & $17,50 \%$ & $-100 \%$ & $213 \%$ \\
\hline
\end{tabular}

Como se percebe, a redução de alíquotas de ICMS aumenta significativamente o lucro das empresas, o que pode inviabilizar a concorrência e a entrada de novos players no mercado.

Porém, como ressalta o Parecer (BRASIL, CADE, 1999, p. 11), o "vetor da guerra fiscal" é a isenção de ICMS em alíquotas interestaduais, e não simplesmente a redução de alíquotas internas do tributo, conforme foi realizado nos estudos de casos demonstrados nos quadros anteriores. Após descrever, então, como funciona o sistema de débitos e créditos de ICMS em operações interestaduais, o CADE chegou aos seguintes 
dados, em setores econômicos diversos, que demonstram a grande variação no lucro líquido unitário dos produtos quando favorecidos com isenção de $7 \%$ e $12 \%$ :

\begin{tabular}{|l|c|c|c|}
\hline & \multicolumn{3}{|c|}{ Lucro líquido unitário dos produtos } \\
\hline Produto & Sem isenção & Isenção de 7\% & Isenção de 12\% \\
\hline Louça sanitária & 5,6 & 10,2 & 13,5 \\
\hline Fumo & 0,9 & 2 & 2,8 \\
\hline Automóvel & 0,4 & 4,7 & 7,8 \\
\hline Sabonete & 2,8 & 6,7 & 9,5 \\
\hline
\end{tabular}

É cristalino, enfim, que a prática da "guerra fiscal" tem um efeito gigantesco sobre a lucratividade das empresas beneficiadas, propiciandoIhes condições significativamente desiguais em relação às demais empresas que concorrem no mesmo setor.

Em suma, pôde-se comprovar que perdas são de diversas ordens. Em primeiro lugar, há o efeito geral de reduzir o grau de eficiência da economia como um todo. Uma empresa poder instalar-se num local em que seu custo seja muito mais alto (por distância do mercado fornecedor ou consumidor, carência de infraestrutura, preparo da mão-de-obra etc.), desde que o incentivo que receba compense essa diferença. Note-se que seu preço final para o consumidor pode até ser menor do que o de seus competidores não incentivados, ou seja, o consumidor pode estar até se beneficiando, entretanto, o consumo de recursos da sociedade continua sendo superior e realizado de forma ineficiente. A coletividade como um todo estará, pois, sendo prejudicada (BRASIL, CADE, 1999, p. 20).

Mais uma vez, demonstra-se que os benefícios fiscais - nesse caso, oriundos da guerra fiscal - são injustos, pois são ineficientes economicamente e provocam perdas de bem-estar para toda a coletividade brasileira. 


\section{Conclusão}

A Análise Econômica do Direito tem o mérito de "trazer o método econômico para a realidade do Direito em um exercício de resultados" (PEREIRA, 2009, p. 71). Com a utilização dessa ferramenta, foi possível demonstrar que políticas fiscais, como mecanismos extrafiscais de correção de falhas de mercado e/ou como estratégias de desenvolvimento econômico regional, apresentam importantes limites.

Para que sejam concedidos, os benefícios fiscais devem ser necessários ou indispensáveis à intervenção do Estado. Haverá de se perguntar, sempre, antes de sua concessão: o que aconteceria se não tivesse que se atribuir o benefício fiscal em causa? Embora haja uma ampla margem de liberdade de prognose para resposta a essa questão, isso não isenta o legislador de prever que, logo após o decurso de certo tempo de concessão do benefício, sejam realizados controles dos seus resultados, a fim de avaliar se a sua necessidade se justifica ao longo do tempo (NABAIS, 1998, p. 664-665).

Os benefícios fiscais devem ser também mais adequados à realização dos objetivos a que se propõem do que outros meios alternativos à disposição dos poderes públicos, sobretudo do que as subvenções diretas. Segundo Nabais (1998, p. 665-666), os benefícios fiscais apenas limitadamente constituem meios adequados de fomento, seja porque são utilizáveis apenas por empresas que estão inseridos no sistema fiscal, seja porque normalmente não são repartidos de maneira equitativamente justa para aqueles que estão inseridos no sistema fiscal, criando vantagens, via de regra, justamente para os que menos precisam.

Finalmente, há que se verificar se os benefícios fiscais são proporcionais stricto sensu, isto é, se não são excessivos, "o que se pode apurar da análise das desvantagens que os benefícios fiscais provocam a terceiros, sobretudo aos concorrentes e das desvantagens gerais delas decorrentes para a generalidade dos contribuintes" (NABAIS, 1998, p. 666-667). 
Em síntese, essas objeções apenas podem ser vencidas pelos benefícios fiscais se, por inequívocas razões do bem comum, eles forem necessários para o fomento da economia no seu todo, efetivamente adequados para a consecução dos respectivos objetivos e calculáveis em termos materialmente justos (NABAIS, 1998, p. 667).

Porém, percebe-se claramente, nos dois casos analisados, que eles não satisfazem nenhum desses critérios. Não são necessários, afinal, se não tivessem sido concedidos, a economia estaria funcionando de forma mais eficiente, gerando menos desperdício e externalidades, e, por isso, gerando mais bem-estar para a coletividade. Não são adequados, pois não são repartidos de maneira equitativa entre os participantes do setor econômico favorecido (ou, talvez, seria melhor falar em desfavorecido). E, por fim, não são proporcionais em sentido estrito, uma vez que são fontes de perceptíveis e importantes problemas de concorrência e desequilíbrio para o desenvolvimento.

De fato, a concessão de benefícios fiscais para uma região ocorre em detrimento de outras regiões, sem que se faça um estudo adequado desses efeitos e dos resultados práticos envolvidos. Assim, o benefício fiscal deve levar em conta os efeitos produzidos em outras regiões, de tal sorte que a maximização de um lado não seja maior que os prejuízos sofridos de outro.

Nesse ponto, as normas devem ser planejadas com o objetivo de causar o máximo de bem-estar para o maior número de pessoas, de modo que os ganhos totais compensem as eventuais perdas sofridas por alguns.

Além do mais, como já revelado, não são eficientes sob as perspectivas de Pareto e de Kaldor-Hicks, aumentam os custos de transação, criam externalidades negativas e ampliam, ainda mais, o poder econômico das maiores empresas. Funcionam, pois, como uma espécie de "Robin Hood às avessas", afinal, a coletividade perde para que poucos ganhem. 


\section{Referências}

ASSUNÇÃO, Matheus Carneiro. Incentivos fiscais em tempos de crise: impactos econômicos e reflexos financeiros. Revista da PGFN, Brasília, v. 1, n. 1, p. 99-123, jan./jun. 2011.

ATALIBA, Geraldo; GIARDINO. Cléber. Isenção para vendas para a ZFM - Finsocial e imposto sobre transportes. Revista de Direito Tributário, São Paulo, n. 41, p.206-220, 1999.

BATISTA, Paulo Nogueira. O consenso de Washington: a visão neoliberal dos problemas latino-americanos. In: LIMA SOBRINHO, Barbosa et al. Em defesa do interesse nacional: desinformação e alienação do patrimônio público. São Paulo: Paz e Terra, 1994.

BATISTA, Paulo Nogueira. O consenso de Washington: a visão neoliberal dos problemas latino-americanos. In: PROGRAMA EDUCATIVO DÍVIDA EXTERNA - PEDEX. Caderno Dívida Externa, n. 6, set. 1994. Disponível em: <http://www.fau.usp.br/cursos/graduacao/ arq_urbanismo/disciplinas/aup0270/4dossie/nogueira94/nog94-conswashn.pdf> Acesso em: 31 jul. 2012.

BORGES MAIOR, José Souto. Teoria geral da isenção tributária. 3. ed. São Paulo: Malheiros, 2007.

BRAGANÇA, Marcel. Efeitos da tributação sobre o direito concorrencial: uma visão harmônica do ordenamento. RDM, São Paulo, v. 133, p.121148, jan./mar. 2001.

BRASIL. Supremo Tribunal Federal. Recurso Extraordinário n ${ }^{\circ}$ 556.6641/RS e 559.882-9/RS. Pleno. Prescrição e decadência tributárias. Matéria reservada à lei complementar. Relator Min. Gilmar Mendes. Diário de Justiça da União, Brasília, DF, 14 nov. 2008.

Conselho Administrativo de Defesa Econômica (CADE). Consulta $n^{\circ}$ 38/1999. Disponível em: <http://www.cade.gov.br/Default. aspx?e142d522e036c85baf53f145>. Acesso em: 23 jun. 2012.

CALIENDO, Paulo. Direito tributário e análise econômica do direito: uma visão crítica. Rio de Janeiro: Elsevier, 2009. 
CARRAZZA, Roque Antonio. Curso de direito constitucional tributário. 25. ed. São Paulo: Malheiros, 2009.

. ICMS. 13. ed. São Paulo: Malheiros, 2009.

CARVALHO, Armando Castelar Pinheiro; SADDI, Jairo. Direito, economia e mercados. Rio de Janeiro: Elsevier, 2005.

CARVALHO, Cristiano; JOBIM, Eduardo. O direito tributário e a interpretação econômica do direito: deveres instrumentais, custos de conformidade e custos de transação. In: TIM, Luciano Benetti et al. (Org.). Direito \& Economia. Porto Alegre: Livraria do Advogado, 2008. p. 239-246.

CARVALHO, Paulo de Barros. Curso de direito tributário. 21. ed. São Paulo: Saraiva, 2009.

CARVALHO, Cristiano. A análise econômica do direito tributário. In: SCHOUERI, Luís Eduardo (Coord.). Direito tributário: homenagem a Paulo de Barros Carvalho. São Paulo: Quartier Latin, 2008. p. 183-207.

COELHO, Fábio Ulhoa. Curso de direito comercial. São Paulo: Saraiva, 2007.

COOTER, Robert; ULLEN, Thomas. Direito \& economia. 5. ed. Porto Alegre: Bookman, 2010.

DAVIS, Kevin E.; TREBILCOCK, Michael J. A relação entre direito e desenvolvimento: otimistas versus céticos. Revista Direito GV, São Paulo, v. 5, n. 1, p. 217-268, jan./jun. 2009.

FORTES, Fellipe Cianca; BASSOLI, Marlene Kempfer. Análise econômica do direito tributário: livre iniciativa, livre concorrência e neutralidade fiscal. Scientia luris, Londrina, v. 14, p. 235-253, nov. 2010.

GICO JÚNIOR, Ivo Teixeira. Metodologia e epistemologia da análise econômica do direito. Economic Analysis of Law Review, v. 1, n. 1, p. 7-32, jan./jun. 2010. Disponível: <http://works.bepress.com/cgi/ viewcontent.cgi?article $=1043 \&$ context=ivo_teixeira_gico_junior $>$. Acesso em: 25 jun. 2012. 
GONÇALVES, Oksandro Osdival. Os incentivos tributários na Zona Franca de Manaus e o desequilíbrio concorrencial no setor de refrigerantes. Economic Analysis of Law Review, Brasília v. 3, n. 1, p. 73-96, jan./jun. 2012.

GRAU, Eros Roberto. A ordem econômica na constituição de 1988. 13. ed. São Paulo: Malheiros, 2008.

GRECO, Marco Aurélio. Planejamento tributário. São Paulo: Dialética, 2004.

LA GUARDIA, Renata. Os efeitos da sonegação fiscal na estrutura tributária ótima: experiência brasileira de aplicação das regras de lumpsum taxation. UC Berkeley: Berkeley Program in Law and Economics, 2007. Disponível em: <http://escholarship.org/uc/item/6995c227>. Acesso em: 29 jun. 2012.

LIMA, Ricardo Seibel de Freitas. Livre concorrência e o dever de neutralidade tributária. 2005. 143 f. Dissertação (Pós-Graduação em Direito)-UFRGS, Faculdade de Direito, PortoAlegre, 2005. Disponívelem: <http://www.lume.ufrgs.br/bitstream/handle/10183/5221/000512454. pdf?sequence=1>. Acesso em: 02 jul. 2012.

MELLO, Celso Antônio Bandeira de. O conteúdo jurídico do princípio da igualdade. São Paulo: Malheiros, 1997.

NABAIS, José Casalta. O dever fundamental de pagar impostos: contributo para a compreensão constitucional do estado fiscal contemporâneo. Coimbra: Almedina, 1998.

NORTH, Douglass. Economic performance through time. Palestra realizada por ocasião do recebimento do Prêmio Nobel em 9 de dezembro de 1993. Disponível em: <http://nobelprize.org/economics/ laureates/1993/north-lecture.html>. Acesso em: 30 jun. 2012.

PINHEIRO, Armando Castelar; SADDI, Jairo. Direito, economia e mercados. Rio de Janeiro: Elsevier, 2005. 
RIBEIRO, Marcia Carla Pereira; GALESKI, Irineu. Teoria geral dos contratos: contratos empresariais e análise econômica. Rio de Janeiro: Elsevier, 2009.

ROTHMANN, Gerd Willi. Tributação, sonegação e livre concorrência. In: FERRAZ, Roberto Catalano Botelho. Princípios e limites da tributação 2: os princípios da ordem econômica e a tributação. São Paulo: Quartier Latin do Brasil, 2009. p. 331-370.

SALAMA, Bruno M. O que é pesquisa em direito e economia?. Cadernos Direito GV, São Paulo, v. 5, n. 2, mar. 2008. Disponível em: <http:// bibliotecadigital.fgv.br/dspace/handle/10438/2811>. Acesso em: 01 jul. 2012.

SCAFF, Fernando Facury. Pareceres: ICMS, Guerra Fiscal e Concorrência na venda de serviços telefônicos pré-pagos. Revista Dialética de Direito Tributário, Brasília, n. 126, 2006.

SCHAPIRO, Mario Gomes. Amarrando as próprias botas do desenvolvimento: a nova economia global e a relevância de um desenho jurídico-institucional nacionalmente adequado. Revista Direito GV, São Paulo, v. 7, n. 1, p. 341-352, jan./jun. 2011.

SEN, Amartya. Desenvolvimento como liberdade. Tradução de Laura Teixeira Motta, revisão técnica Ricardo Doninelli Mendes. São Paulo: Companhia das Letras, 2010.

SHIRLEY, Mary M. Institutions and development. In: MÉNARD, Claude; SHIRLEY, Mary M. Handbook of new institutional economics. Netherlands: Springer, 2008. p. 611-638.

SIMÕES, Tiago Landi. O critério espacial do IPVA e a guerra fiscal entre os Estados. Revista de Direito Público, Londrina, v. 4, n. 1, p. 173-184, jan./abr. 2009.

SOUZA, Hamilton Dias de. Livre concorrência: Desvios concorrenciais tributários e a função da Constituição. Consultor Jurídico, São Paulo, 21 set. 2006. Disponível em: <http://www.conjur.com.br/2006-set-21/ desvios_concorrenciais_tributarios_funcao_constituicao>. Acesso em: 01 jul. 2012. 
SPINELLI, Luis Felipe. A teoria da firma e a sociedade como organização: fundamentos econômico-jurídicos para um novo conceito. Revista de Direito Mercantil, Industrial, Econômico e Financeiro. Nova série, São Paulo, ano 46, n. 146, p. 169, abr./jun. 2007.

SZTAJN, Rachel. Laws \& Economics. In: SZTAJN Rachel; ZYLBERSTAJN, Décio (Org.). Direito \& Economia: análise econômica do direito e das organizações. Rio de Janeiro: Elsevier, 2005. p. 74-84.

. Law and economics. Revista de Direito Mercantil, Industrial, Econômico e Financeiro. Nova série, São Paulo, ano 44, n. 137, p. 227, jan./mar. 2005.

. Externalidades e custos de transação: a redistribuição de direitos no novo Código Civil. Revista de Direito Mercantil, Industrial, Econômico e Financeiro. Nova série, São Paulo, ano 43, n. 133, p. 7-31, jan./mar. 2004.

TRAMONTIN, Odair. Incentivos fiscais a empresas privadas \& guerra fiscal: uma análise crítica, baseada em princípios constitucionais, sobre a existência de interesse público nas concessões de incentivos a empresas de fins. Curitiba: Juruá, 2002.

VARSANO, Ricardo. A guerra fiscal do ICMS: quem ganha e quem perde. Planejamento e Políticas Públicas, Brasília, n. 15, p. 13-18, jun. 1997. Disponível em: <http://www.ipea.gov.br/sites/000/2/ppp/pdf/ ppp15.pdf>. Acesso em: 29 jun. 2012.

Recebido em: 11/03/2015

Aprovado em: 03/04/2015 